\title{
超分子手性组装体的构建与应用
}

\author{
刘金果 ${ }^{a}$ 殷 凤 ${ }^{a}$ 胡君*,b 巨勇*,a \\ ( ${ }^{a}$ 清华大学化学系 生命有机磷化学及化学生物学教育部重点实验室 北京 100084) \\ ${ }^{b}$ 北京化工大学 北京软物质科学与工程高精尖创新中心 北京 100029)
}

\begin{abstract}
摘要 超分子手性组装体通常由多种非共价相互作用协同驱动形成, 是一类具有独特手性限域微环境的软物质, 对材 料工程、生命科学、光学器件、催化合成等领域的发展具有重要作用. 其主要构建方法分为三种: 手性基元组装、手 性因素诱导非手性基元组装、非手性基元对称性破缺组装. 通过分析近年来的研究成果，归纳了利用这三种方法构建 超分子手性组装体的一般策略, 并简要综述了超分子手性组装体在手性模板、手性识别、圆偏振发光及不对称催化领 域中的应用进展与亟需弥补的缺陷. 随着研究的深入, 手性传递机制将得到进一步解释, 未来将有助于人们理解生命 体内的手性现象, 有望最终解答自然界中的手性起源问题.
\end{abstract}

关键词＼cjkstart超分子手性组装体；手性模板；手性识别; 圆偏振发光; 不对称催化

\section{Fabrication and Applications of Supramolecular Chiral Assemblies}

\author{
Liu, Jinguo $^{a} \quad$ Yin, Feng $^{a} \quad \mathrm{Hu}$, Jun $^{*, b} \quad$ Ju, Yong ${ }^{*, a}$ \\ ( ${ }^{a}$ Key Laboratory of Bioorganic Phosphorus Chemistry and Chemical Biology, Ministry of Education, \\ Department of Chemistry, Tsinghua University, Beijing 100084) \\ ( ${ }^{b}$ Beijing Advanced Innovation Center for Soft Matter Science and Engineering, Beijing University of \\ Chemical Technology, Beijing 100029)
}

\begin{abstract}
As a kind of soft materials promoted by multiple noncovalent interactions, supramolecular chiral assemblies own the distinctive confined chiral microenvironment and play an important role in material engineering, life science, optical devices and catalytic synthesis. In general, supramolecular chiral assembles can be fabricated through the assembly of chiral molecules, or a combination of achiral molecules and chiral inducements, or mere achiral molecules in symmetry breaking manner. In this paper, the general fabrication strategies of supramolecular chiral assemblies in recent years are summarized, and their improvements in chiral template, chiral recognition, circularly polarized luminescence and asymmetric catalysis are briefly reviewed, as well as the shortcomings in these fields. With the development of supramolecular chiral assemblies, the mechanism of chirality transfer will be explained in depth in future, which may help us understand the chirality phenomenon in organism and give a clue to answer to the origin of homochirality in nature.
\end{abstract}

Keywords supramolecular chiral assembly; chiral template; chiral recognition; circularly polarized luminescence; asymmetric catalysis

手性在自然界和生物体内普遍存在，表示一种对称 性特征，即如果一个物体与其镜像无法重合，则称其具 有手性. 在分子中, 手性的来源主要是分子的不对称中 心、不对称轴或不对称面 ${ }^{[1]}$. 在超分子领域中, 一些分子 能够在氢键、范德华力、 $\pi-\pi$ 堆积等多种非共价作用的 协同下手性排列聚集, 形成螺旋、纽带等有序组装体 ${ }^{[2-3]}$, 使原本不具有手性的分子或基团产生手性信号, 或者使 原有手性以非线性的形式被放大, 这种现象称为超分子
手性 ${ }^{[4]}$. 超分子手性不仅与基元本身的手性和结构有

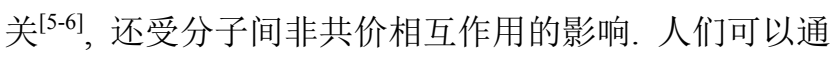
过溶剂 ${ }^{[7]} 、 \mathrm{pH}^{[8]}$ 、温度 ${ }^{[9]}$ 、光 ${ }^{[10]}$ 、离子 ${ }^{[1]}$ 等手段对其进 行调控，丰富了超分子手性组装体的类型，为其在不同/ 领域中的应用提供夯实的物质基础. 值得注意的是, 超 分子手性组装体的整体性质不是各个基元的简单叠加, 它具备单独基元所没有的独特空间限域的手性立体结 构. 因此, 如何有效设计和构建特定结构与功能的超分

* Corresponding authors. E-mail: jhu@mail.buct.edu.cn; juyong@mail.tsinghua.edu.cn

Received August 10, 2020; revised September 10, 2020; published online September 29, 2020.

Project supported by the National Natural Science Foundation of China (Nos. 21772112, 21604085).

国家自然科学基金(Nos. 21772112, 21604085)资助项目. 
子手性组装体, 已引起超分子化学家们的广泛关注. 本 文在分析近年来国内外相关研究成果的基础上, 结合本 课题组在超分子手性组装方面的研究经验, 围绕组装过 程中超分子手性的来源, 着重概述超分子手性组装体的 构建方式, 并简述超分子手性组装体在手性模板、手性 识别、圆偏振发光和不对称催化领域的研究进展与发展 趋势, 以期为相关研究工作提供帮助, 促进超分子手性 组装领域的发展.

\section{2 超分子手性组装体的构建方法}

根据组装过程中超分子手性的来源分类, 可以将超 分子手性组装体的构建方法分为三类: (1)手性基元自组 装形成有序超分子结构. 手性从基元传递至组装体, 产 生单个分子在自由状态下不具备的手性特征. (2)手性因 素诱导非手性基元在组装体中产生手性信号. (3)非手性 基元在组装过程中发生对称性破缺, 形成有序的超分子 手性结构.

\section{1 手性基元的超分子手性组装}

在手性基元自组装的过程中, 手性通过非共价相互 作用从基元本身传递至组装体. 方法简便, 可控度高, 且所得组装体的手性特征与构筑基元的分子手性密切 相关 ${ }^{[12]}$. 自然界中的手性小分子种类繁多, 如糖、氨基 酸、甾体、三萜等, 它们具有独特的手性中心, 经结构 修饰后通常能成为性质优良的手性基元 ${ }^{[13-16]}$. 由于这些 手性小分子结构各异, 因此在构建超分子手性组装体时 的设计思路各有不同. 下面将依次介绍如何利用糖、氨 基酸、甾体、三萜这四类天然手性小分子构建手性组装 体.

糖是生命体重要的能量来源和结构物质. 糖类化合 物含有多个羟基，具有强烈的形成分子间氢键的趋势, 且大部分糖水溶性较好, 可作为组装基元的亲水部分. 向糖类化合物中引入苯、偶氮苯、三嗪、富勒烯等芳香 疏水基团, 可以在改变亲疏水平衡的同时, 赋予组装基 元 $\pi-\pi$ 作用, 促进基元在多重非共价力的协同作用下有 序组装, 形成超分子手性结构 ${ }^{[17-18]} .2001$ 年, Shimizu 课 题组 ${ }^{[19]}$ 报道了基于 $D$-葡萄糖的两亲性分子 $\mathbf{1}$ 组装形成 的螺旋纤维凝胶 (图 1a), 通过核磁共振氢谱证明, 凝胶 形成的驱动力为氢键与 $\pi-\pi$ 作用. 研究还表明在组装基 元中引入芳香基团, 能够促进基元的线性平行排列, 提 高组装结构的刚性. 但也不能一概而论所有糖-芳基组 装体形成的驱动力均是氢键和 $\pi-\pi$ 作用, 需要结合实验 结果和理论计算具体分析. 例如, Birchall 课题组 ${ }^{[20]}$ 设计 合成的 Fmoc- $D$-葡萄糖胺 2 和 Fmoc- $D$-半乳糖胺 3 (图 1b) 在组装时以 “ $\mathrm{T}$ ” 形排列, 基元间不存在有效的氢键和 $\pi-\pi$ 作用, 促进组装的驱动力为 Fmoc 基团与葡萄糖上
$\mathrm{CH}$ 间的 $\mathrm{CH}-\pi$ 作用.

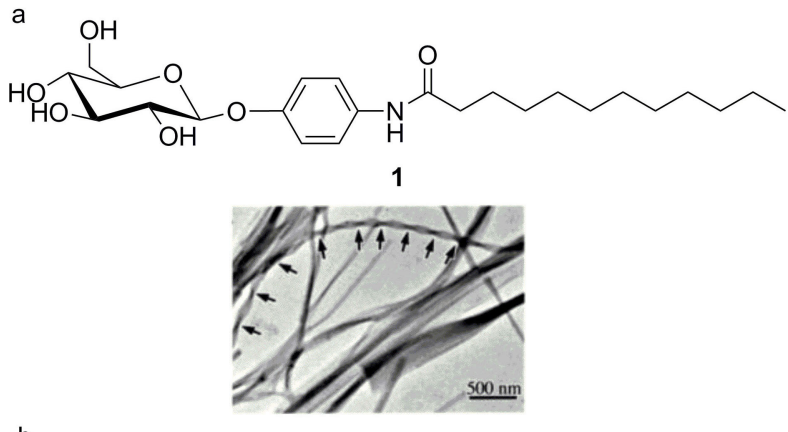

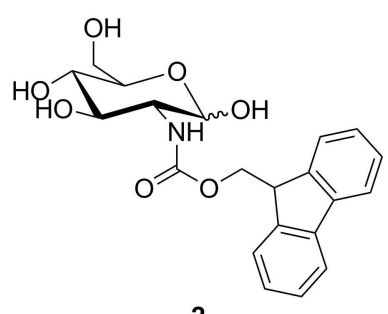

2

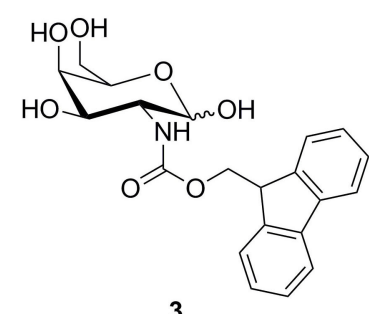

图 1 (a) $D$-葡萄糖衍生物 $\mathbf{1}$ 的化学结构式和组装体的透射电 镜图 ${ }^{[19]}$, 以及(b) Fmoc- $D$ - 葡萄糖胺 $\mathbf{2}$ 及 Fmoc- $D$-半乳糖胺 $\mathbf{3}$ 的化学结构式 ${ }^{[20]}$

Figure 1 (a) Chemical structures of $D$-glucose-based amphiphile 1 and TEM image of its assembly ${ }^{[19]}$, and (b) chemical structures of Fmoc- $D$-glucosamine 2 and Fmoc- $D$-glucosamine $3^{[20]}$

菲酰亚胺具有较大的共轭平面, 在组装时能提供强 $\pi-\pi$ 作用，促进基元间有序聚集，被广泛应用于糖类手 性组装体的构建和调控 ${ }^{[21]}$. 李志波课题组 ${ }^{[22]}$ 通过 Click 反应将芢酰亚胺与 $D$-葡萄糖连接, 合成了能在甲醇/水 混合溶剂中组装的两亲性化合物 4. 其在 4 和 $25{ }^{\circ} \mathrm{C}$ 分别 形成亚稳态的左手螺旋纤维和稳态的片层结构，前者在 升温时向后者转化(图 2). 在不同温度下, 组装基元间氢 键、 $\pi-\pi$ 作用和亲疏溶剂作用的强度发生改变, 导致不 同纳米结构的形成, 实现了温度对手性组装体形貌的调 控.

由于在基元中引入偶氮苯基团, 不仅能提供 $\pi-\pi$ 作 用, 还赋予组装体光响应性，因此基于糖-偶氮苯两亲 性分子的组装体也有大量报道 ${ }^{[23-25]}$. Kitaoka 等 ${ }^{[25]}$ 设计 合成了偶氮苯修饰的 $\beta$ - $D$-乳糖衍生物 5、 $\beta$ - $D$-麦芽糖衍 生物 6 和 $\beta-D$-纤维二糖衍生物 7. 在氢键和 $\pi-\pi$ 作用的 协同下, $5 \sim 7$ 均发生组装, 且 5 和 6 在水中形成稳定凝 胶，但三者不同的糖基位阻导致分子堆积时氢键方向和 芳环取向的差异，进而形成三种不同结构的超分子组装 体. 尽管 5 和 6 凝胶均为纤维形貌(图 3), 未能直接观测 到手性结构, 但从圆二色谱(CD)中可以发现, 5 形成右 手螺旋结构, 6 形成右手螺旋结构, 7 的组装体则没有任 
何手性特征. 在紫外光辐照下偶氮苯发生光异构化, 破 坏 $\pi-\pi$ 作用, 使三种组装体解离, 宏观上发生凝胶-溶胶 转变.

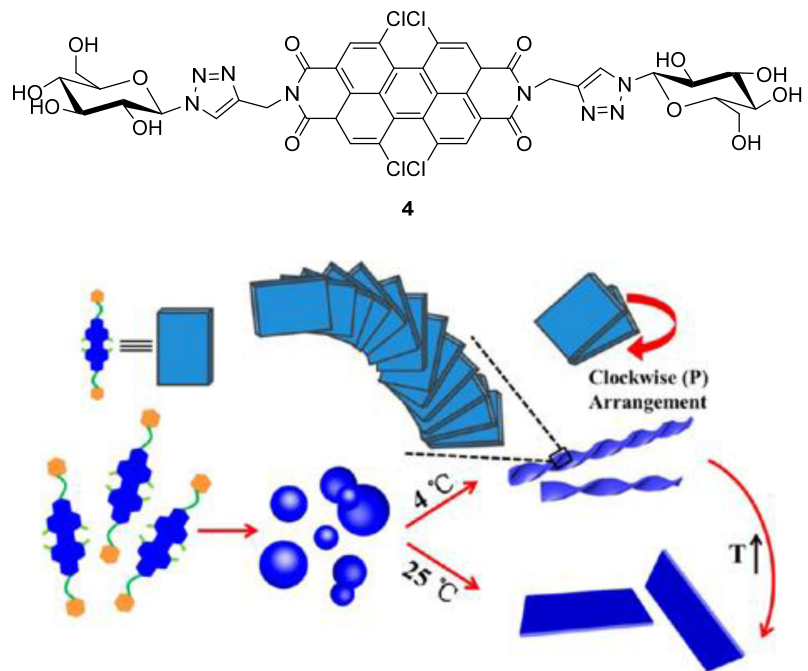

图 2 化合物 4 形成左手螺旋与片层两种组装体的示意图 ${ }^{[22]}$ Figure 2 Illustration of the self-assembly for twisted ribbons and microplates of $\mathbf{4}^{[22]}$
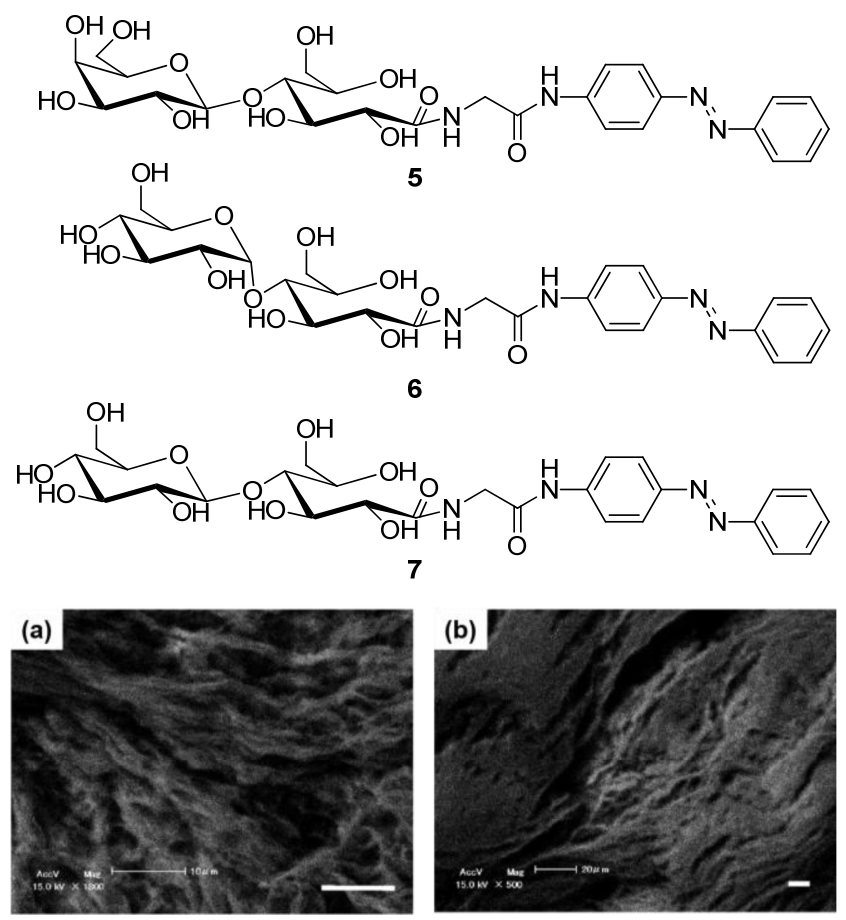

图 3 二糖偶氮苯衍生物 5 7 以及组装体(a) 5 和(b) 6 的原位 低压扫描电镜图(标尺: $1 \mu \mathrm{m})^{[25]}$

Figure 3 Disaccharide-azobenzene compounds $5 \sim 7$, and in situ LVSEM images of their assemblies (a) 5 and (b) $\mathbf{6}$ (scale bar: $1 \mu \mathrm{m})^{[25]}$

天然氨基酸(除 Gly 外)均具有手性，它们结构多样, 化学性质丰富: Asp、Glu、His、Arg 和 Lys 具有带电性, Phe、Tyr 和 Trp 具有芳香性, Ser、Thr、Gln 和 Asn 亲水
而 Ala、Val、Leu、Ile 和 Met 疏水. 此外，它们易于修 饰，彼此缩合成肽的酰胺连接臂能提供良好的氢键位 点. 可见, 氨基酸能够提供电荷作用、 $\pi-\pi$ 作用、亲疏溶 剂作用和氢键多种非共价作用力 ${ }^{[14,26]}$, 是一类优良的组 装基元.一些天然多肽序列，如胰岛素、溶菌酶等蛋白 质片段未经修饰就能在水中形成有序的螺旋纤维, 螺旋 方向还可以通过 $\mathrm{pH}$ 调控 ${ }^{[27]}$. 在人工合成氨基酸衍生物 基元时，可以通过向其引入长链烷基、芳香基团等疏水 基团降低水溶性或引入电荷中心提高水溶性，也可以同 时引入这两种基团达到亲疏水平衡 ${ }^{[14]}$. 相比于天然多 肽序列，这些人工合成的组装基元结构相对简单，有利 于人们分析基元结构与超分子手性之间的关系，从而设 计具有特定手性结构的组装体.

赵彦利课题组 ${ }^{[28]}$ 将对 $D$-苯丙氨酸用对苯二甲酸桥 连, 合成的手性基元 8 在氢键和 $\pi-\pi$ 作用下形成手性纳 米螺旋纤维，且在改变分子结构中的非手性部分后，组 装体的超分子手性发生逆转. 如图 4 所示, 8 组装形成 $M$ 型左手螺旋纤维，而末端羧基被非手性乙氧基链段修饰 的 9 则形成 $P$ 型右手螺旋纽带. 虽然末端羧基修饰没有 改变分子的手性中心, 但引入的乙氧基链段提供了额外 的分子间氢键位点, 导致基元堆积时取向发生改变, 引 起超分子手性的逆转.
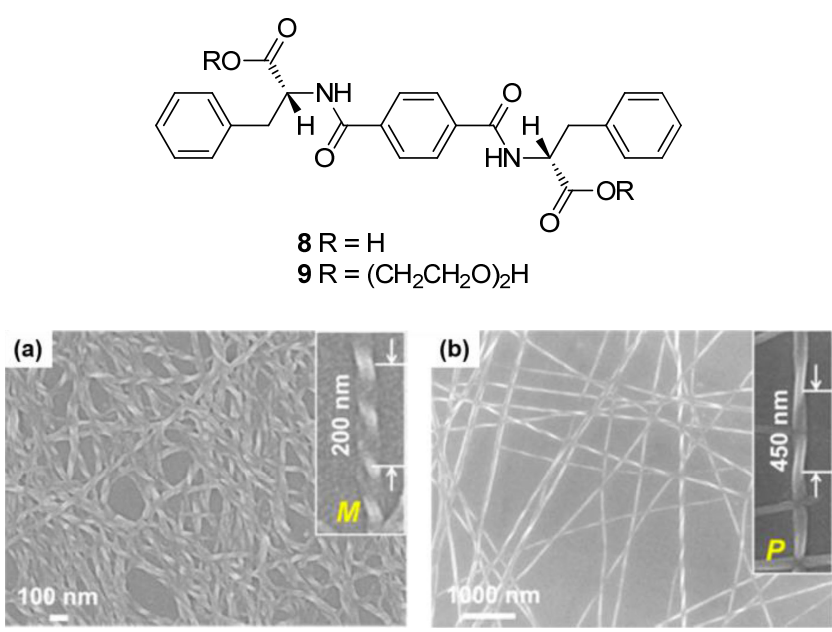

图 $4 D$-苯丙氨酸衍生物 $8 \sim 9$ 以及其组装体(a) 8 和(b) 9 的扫 描电镜图 ${ }^{[28]}$

Figure 4 Chemical structures of $D$-phenylalanine derivatives $\mathbf{8} \sim \mathbf{9}$ and SEM images of assemblies of (a) 8 and (b) $9^{[28]}$

杨永刚等 ${ }^{[29]}$ 将线氨酸修饰在长烷基链上，再向两 侧引入吡啶盐基团, 合成了互为对映体的 Bola 型两亲 性分子 DD-10 和 $\boldsymbol{L L}-10$ (图 5). 疏水烷基链和亲水吡啶盐 使分子达到了合适的亲疏水平衡，在水中形成稳定的手 性螺旋带，且螺旋带的手性取决于坃氨酸的手性. 尽管 吡啶盐具有平面共轭的芳香性, 但 $\mathrm{CD}$ 光谱中并没有吡 啶盐的信号峰，因此推断组装的驱动力是酰胺提供的氢 
键与烷基链间的范德华力. 虽然吡啶盐未能有效提供 $\pi-\pi$ 作用, 但它的正电性为负电的二氧化硅前体提供了 生长位点, 使该体系成功应用于螺旋二氧化硅材料的制 备.

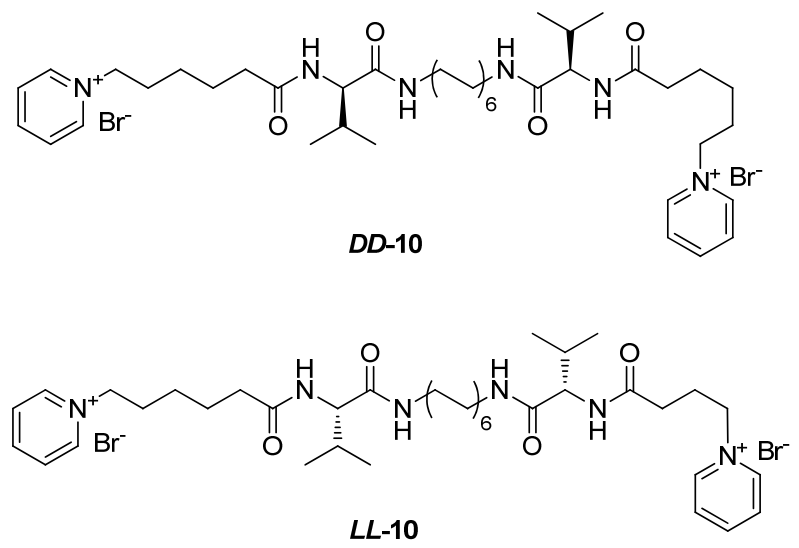

图 5 Bola 型两亲性颉氨酸衍生物 $D D-10$ 和 $\boldsymbol{L} \boldsymbol{L}-\mathbf{1 0}^{[29]}$

Figure 5 Chemical structures of Bola-type valine-based amphiphiles $\boldsymbol{D D}-10$ and $\boldsymbol{L} \boldsymbol{L}-\mathbf{1 0}^{[29]}$

Stang 等 ${ }^{[30]}$ 通过丙氨酸衍生物 $\boldsymbol{D} / \boldsymbol{L}-\mathbf{1 1}$ 与 $\mathrm{Pt}$ 的配位 键构建了手性金属环. 12 和 13 不同的配体结构使 $D / L-11$ 与它们分别形成棱形和六边形两种金属环 $D / L-14$ 和 $D / L-15$ (图 6a), 但它们在芳环吸收区均没有 $\mathrm{CD}$ 信号, 表明手性未能通过配位键在该分子中传递. 但这两种金属环在氢键、疏水作用和 $\pi-\pi$ 作用下组装, 同时手性从丙氨酸的 $\alpha$ 碳原子传递至芳环, 进一步传至 超分子组装体结构中, 形成手性螺旋形貌. 螺旋的手性 取决于丙氨酸的手性, 与金属环的形状无关(图 $6 \mathrm{~b} \sim 6 \mathrm{e}$ ).

相比其他多手性中心的天然小分子, 氨基酸的手性 来自 $\alpha$ 碳原子, 易于控制, 简化了影响组装体超分子手 性的因素, 便于研究对映体混合物共组装时的手性传递 过程. 刘鸣华课题组 ${ }^{[31]}$ 制备了 Fmoc 和烷基链修饰的丙 氨酸衍生物 $D / L-16$, 它在 $\pi-\pi$ 作用、氢键和烷基链的范 德华力作用下组装成纳米带结构, 并且组装体表现出 “多数效应”，即在对映体混合物共组装时，整体的超 分子手性并不随 $e e$ 值线性变化, 较小的 $e e$ 值就可以决 定整个组装体的超分子手性. 在 $D / L-16$ 混合物中, \pm $2 \%$ 的 $e e$ 值就足以诱导纳米带卷曲形成 $P$ 型或 $M$ 型螺旋 (图 7).

江云宝等 ${ }^{[32}$ 通过苯丙氨酸的硫醇衍生物 $D / L-17$ 与 银离子配位, 构建了一维线性超分子组装体, 其手性与 $\boldsymbol{D} / \boldsymbol{L}-\mathbf{1 7}$ 混合物的 $e e$ 值表现出 “多数效应”, 但同时也 存在 “外消旋效应”. D/L-17 在分子内氢键的作用下形 成十元环的 $\beta$ 转角二级结构. 颈基与银离子配位后, 进 一步在 $\mathrm{Ag}^{+} \cdots \mathrm{Ag}^{+}$相互作用下组装成线性结构(图 8). 组 装体的 $\mathrm{CD}$ 光谱显示, 手性通过 $\beta$ 转角从苯丙氨酸手 (a)

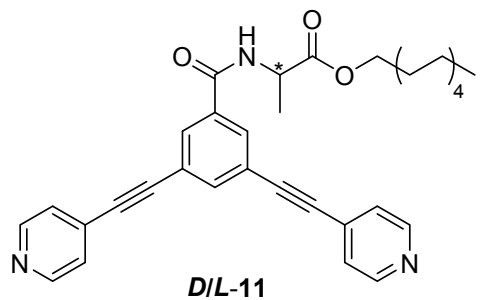

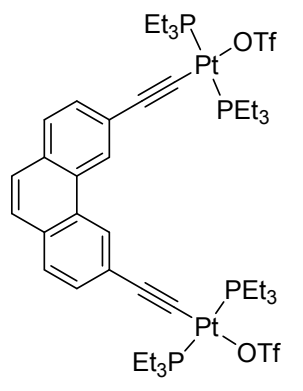

12

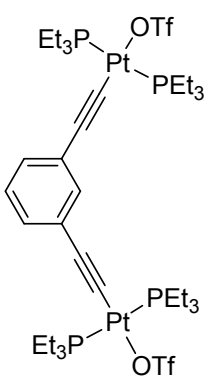

13

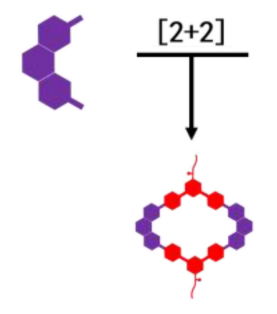

D/L-14
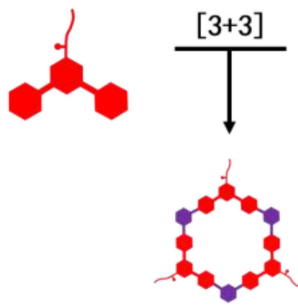

$D / L-15$
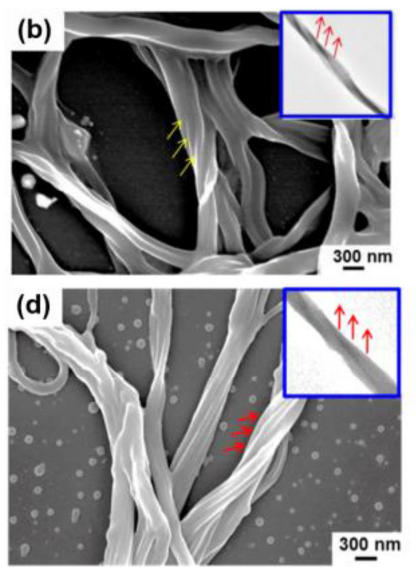
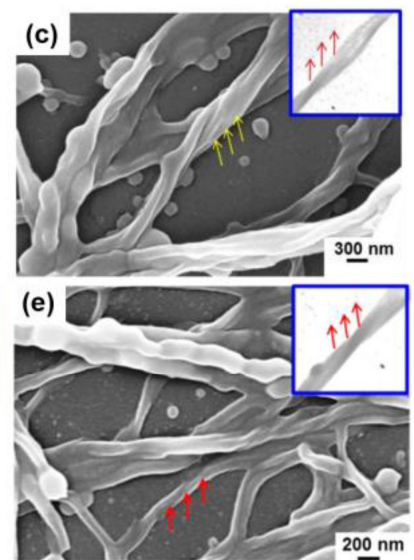

图 6 (a) $D / L-11 、 12 、 13$ 的化学结构式和它们形成棱形和六 边形金属环的示意图，以及(b) D-14, (c) $L-14$, (d) D-15, (e) $L-15$ 凝胶的扫描电镜图 (插图为对应的透射电镜图) ${ }^{[30]}$

Figure 6 (a) Chemical structures of $D / L-11,12,13$ and illustration of the formation of metallacycles rhomboids and hexagons, SEM images of gels of (b) D-14, (c) $L-14$, (d) $D-15$, (e) $L-15$ (Inset: corresponding TEM images) $^{[30]}$

性中心传递至硫脲基团, 硫脲基团的超分子手性与 $e e$ 值具有 “多数效应” ，较小的 $e e$ 值即可决定硫嫝基团 的超分子手性. 与此同时，手性通过配位作用传递至银 离子链后, $\mathrm{Ag}^{+} \cdots \mathrm{Ag}^{+}$结构的超分子手性则表现出 “外 消旋效应” , 即与 “多数效应” 相反, 超分子手性信号 与 $e e$ 值非线性, 需更高的 $e e$ 值才能诱导产生超分子手 
性
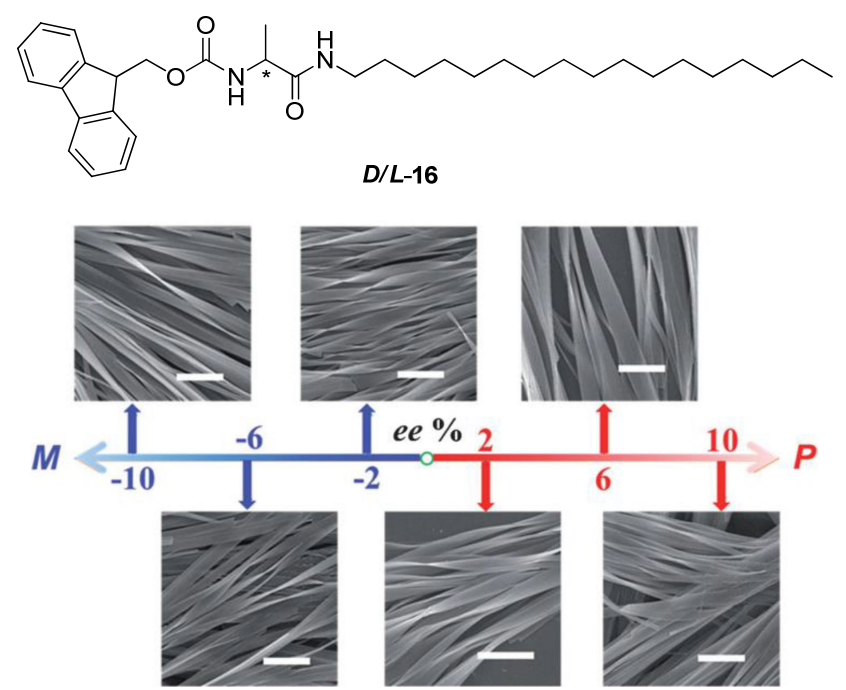

图 $7 \quad D / L-16$ 的化学结构及其共组装体形貌随 $e e$ 值变化的扫 描电镜图(标尺: $5 \mu \mathrm{m}$ ) ${ }^{[31]}$

Figure 7 Chemical structures of $\boldsymbol{D} / \boldsymbol{L}-\mathbf{1 6}$ and SEM images of their co-assemblies with various $e e$ values (scale bar: $5 \mu \mathrm{m})^{[31]}$

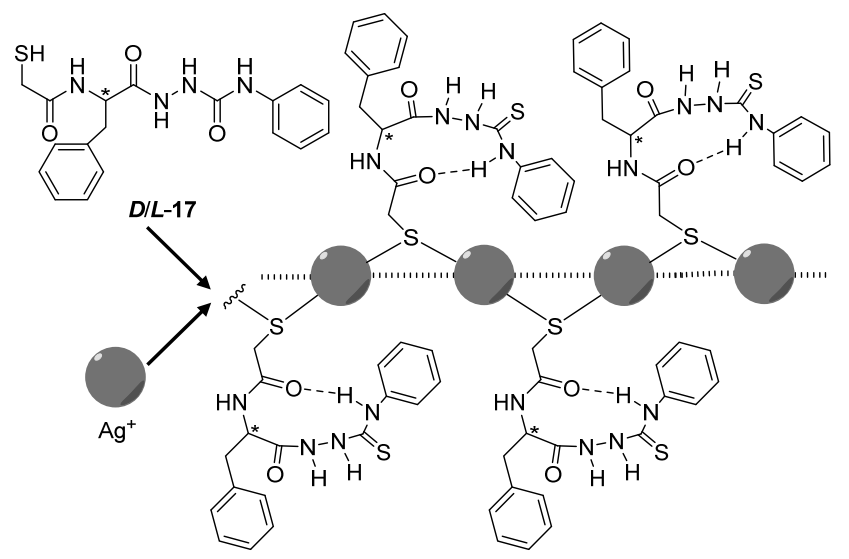

图 $8 D / L-17$ 的化学结构及其与 $\mathrm{Ag}^{+}$组装成线性超分子结构 的示意图 ${ }^{[32]}$

Figure 8 Chemical structures of $\boldsymbol{D} / \boldsymbol{L}-\mathbf{1 7}$ and illustration of the linear supramolecular structure assembled form $D / L-17$ and $\mathrm{Ag}^{+[32]}$

甾体是一类以环戊烷骈多氢菲为母核的生物源四 环化合物, 分子长度介于糖类、氨基酸等简单小分子和 多肽、DNA 等大分子之间, 具有独特的手性骨架结构, 在超分子领域得到了广泛研究 ${ }^{[33]}$. 相比于糖和氨基酸, 甾体最显著的特点就是它的亲脂疏水性, 组装过程多发 生在低极性有机溶剂中, 只有向其引入强亲水结构, 如 电荷中心 ${ }^{[34]}$ 才能实现在水相中的组装. 尽管甾体的手 性刚性骨架可以使自身形成手性组装体，例如 Konikoff 等 ${ }^{[35]}$ 在 1992 年就发现了胆固醇在结晶过程中的螺旋结 构, 但为了更有效地诱导手性从分子水平传递到超分子 水平, 人们往往引入 $\pi-\pi$ 作用、氢键等具有取向性的非
共价作用力 ${ }^{[36-37]}$ 来构建手性组装基元，其中基于胆固醇 和胆甾酸基元的报道较多.

赵彦利等 ${ }^{[38]}$ 设计合成了偶氮吡啶修饰的胆固醇基 元 18, 在 $\pi-\pi$ 作用和胆固醇骨架间范德华力驱动下，在 DMSO 中组装形成超分子手性凝胶, 微观形貌为二维片 层结构. $365 \mathrm{~nm}$ 紫外光引发的偶氮反一顺异构使片层结 构初步卷曲成一维纳米管, 最终形成零维的不规则纳米 颗粒，超分子手性随之消失. 此外，由于金属离子与吡 啶 $\mathrm{N}$ 原子间的配位作用，在正丁醇中外加不同金属离子 时, 18 可以组装形成不同的超分子手性结构: 加入 $\mathrm{Ni}^{2+} 、 \mathrm{Eu}^{3+}$ 时形成 $M$ 型左手螺旋, 加入 $\mathrm{Cu}^{2+} 、 \mathrm{Bi}^{3+}$ 时形 成 $P$ 型右手螺旋(图 9).
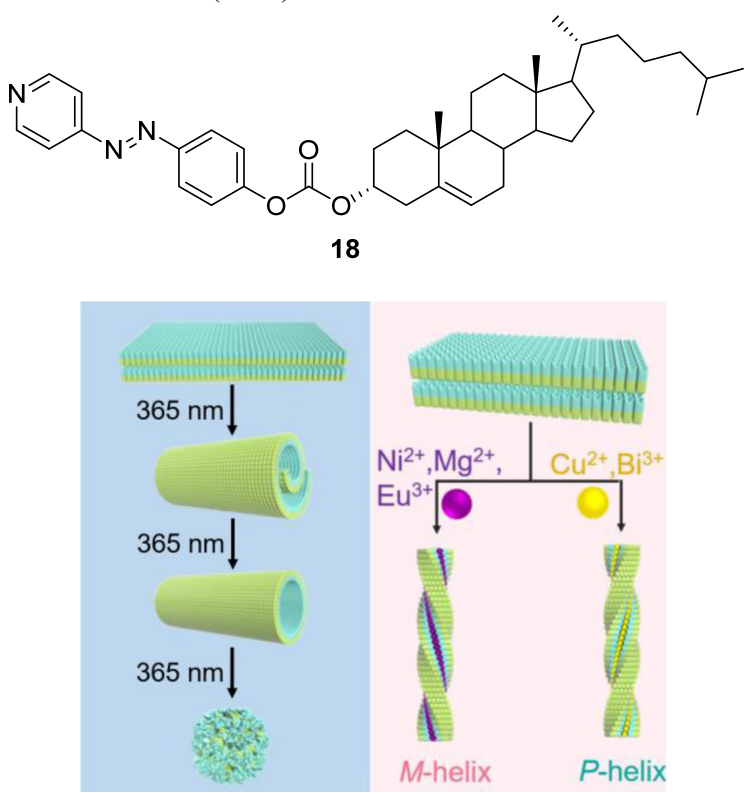

图 9 胆固醇-偶氮吡啶分子 18 及紫外光、金属离子对组装体 维度和超分子手性的调控 ${ }^{[3]}$

Figure 9 Chemical structure of cholesterol-azopyridine conjugate 18, and control on dimensions and supramolecular chirality of it sassemblies through UV and metal ions ${ }^{[38]}$

胆甾酸除拥有甾体本身的结构性质外，还具有独特 的面式两亲性, 即分子的 $\alpha$ 面疏水、 $\beta$ 面相对亲水, 在组 装过程中会发生多级组装 ${ }^{[33]}$. 我们 ${ }^{[39]}$ 制备了寊聚对苯 撑乙炔桥连的胆甾酸二聚体 $19 \sim 21$. 在四氢呋喃/水混 合溶剂中，酰胺键的氢键和对苯撑乙炔间的 $\pi-\pi$ 作用驱 动对苯撑乙炔面面重叠排列, 19 中胆酸基团亲水性相对 较高，可以自由暴露在溶剂中形成囊泡(图 10a). 由于 20 中去氧胆酸基团的疏水性比 19 中的胆酸高, 因此在 对苯撑乙炔的一级组装基础上，去氧胆酸基团间通过疏 水作用和分子间氢键结合, 形成二级组装体. 分子组装 过程中去氧胆酸的手性得以传递至组装体，得到如图 $10 \mathrm{~b}$ 所示的手性螺旋结构. 此外, 石胆酸的强疏水性使 分子整体的亲疏水平衡被破坏, 21 无法在四氢呋喃/水 
混合溶剂有效组装.
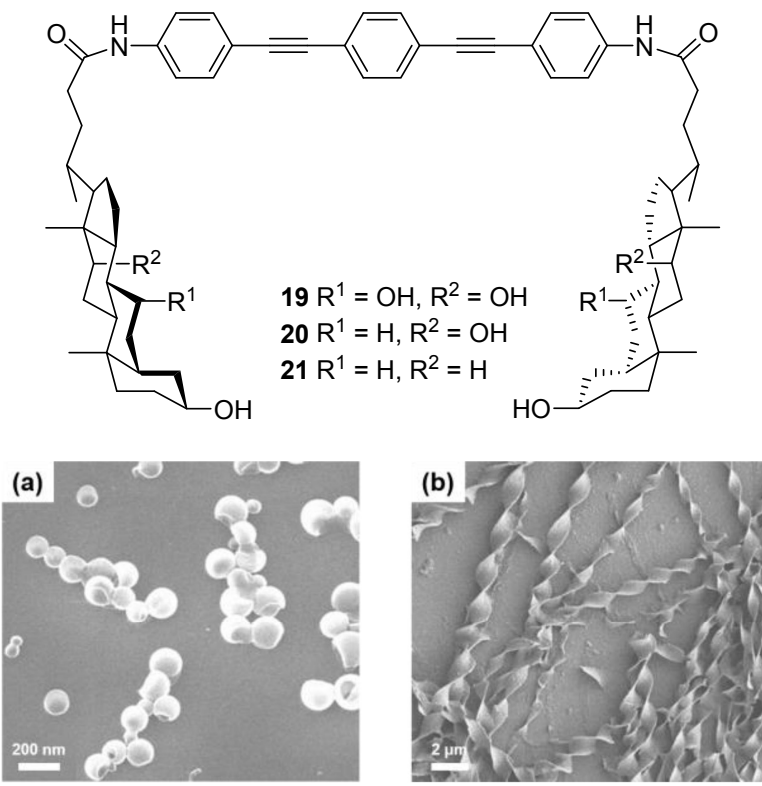

图 10 胆甾酸衍生物 19 21 的化学结构式及组装体 19 (a)和 20 (b)的扫描电镜图 ${ }^{[39]}$

Figure 10 Chemical structures of bile acid derivatives 19 $\sim 21$, and SEM images of assemblies of $\mathbf{1 9}$ (a) and $\mathbf{2 0}(\mathrm{b})^{[39]}$

三萜是由六个异戍二烯单元构成的一类天然产物, 其中五环三萜及其衍生物在分子组装领域报道广泛 ${ }^{[40]}$. 五环三萜与甾体生物同源, 具有刚性疏水骨架和多个手 性中心，但它缺少甾体结构中的柔性侧链，骨架刚性更 强, 在溶剂中更易保持刚性结构, 表现出有序聚集的趋 势. 许多天然三萜化合物能够在各类溶剂中发生超分子

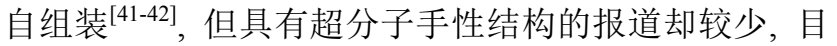
前仅有 Mezzenga 等报道的甘草酸 22 一例 ${ }^{[43]}$, 它能在水
中自组装成右手螺旋纤维(图 11). 与甾体的衍生化思路 类似，将五环三萜骨架上的羟基和羧基作为反应位点， 引入功能基团与对应的非共价键，调节基元间的相互作 用，可以更好地制备出具有手性的超分子结构.

我们课题组设计合成的 2,3-二肜基齐墩果酸 23 能 够在分子间氢键的驱动下组装, 并凝胶化氯仿、甲苯等 多种有机溶剂 ${ }^{[44]}$. 尽管凝胶微观形貌为纤维网络状，但 该凝胶与非手性甲酚红染料共组装时，能通过手性传递 诱导染料在圆二色谱中表现出 Cotton 效应(图 12). 在加 热条件下组装体被破坏，手性信号随之消失，证明组装 体具备单个分子所不具有的超分子手性.

我们进一步对基于三萜骨架的超分子手性组装基 元的结构设计进行了研究 ${ }^{[45]}$. 甘草次酸吡啶盐衍生物 24 能在吡啶间 $\pi-\pi$ 作用、骨架间范德华作用力的协同驱 动下有序排列成超分子手性螺旋结构. 将该结构进行扩 展，其他三种结构相近的三萜-吡啶盐分子 $\mathbf{2 5} \sim \mathbf{2 7}$ 也被 发现能够形成规整的手性结构(图 13), 表明三萜-吡啶 盐分子结构是一个潜在的普适性手性组装基元.

糖、氨基酸、甾体和三萜等天然手性小分子来源广 泛，生物相容性好. 人们根据这些小分子自身的结构特 点, 通过向其引入能提供非共价相互作用的官能团, 实 现基元有序排列，获得结构各异的超分子手性组装体. 该方法极大地简化超分子手性组装体的制备过程，赋予 组装体环保及生物相容的特性. 这种构建方式不仅仅是 超分子化学家最常用的高效方式，也是自然界与生命体 内最为广泛的形式. 在组装过程中, 化学家模仿自然、 理解自然，对深入探索自然界与生命体内的手性过程具 有重要意义.

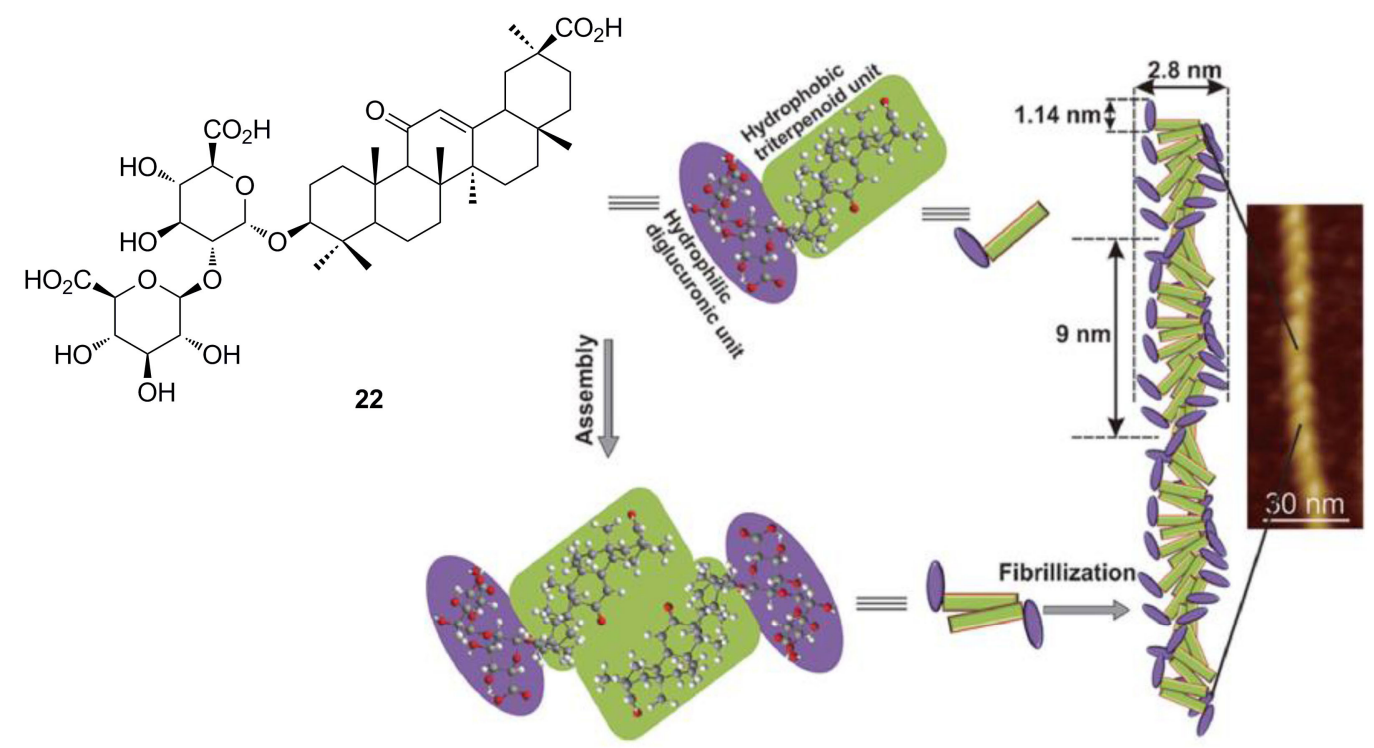

图 11 甘草酸 22 在水中自组装形成右手螺旋纤维的示意图 ${ }^{[43]}$

Figure 11 Illustration of right-handed fibrils assembled from 22 in water ${ }^{[43]}$ 
<smiles>CC1(C)CCC2(C(=O)O)CC[C@]3(C)C(=CCC4[C@@]5(C)CC(=O)C(=N)C(C)(C)C5CC[C@]43C)C2C1</smiles>

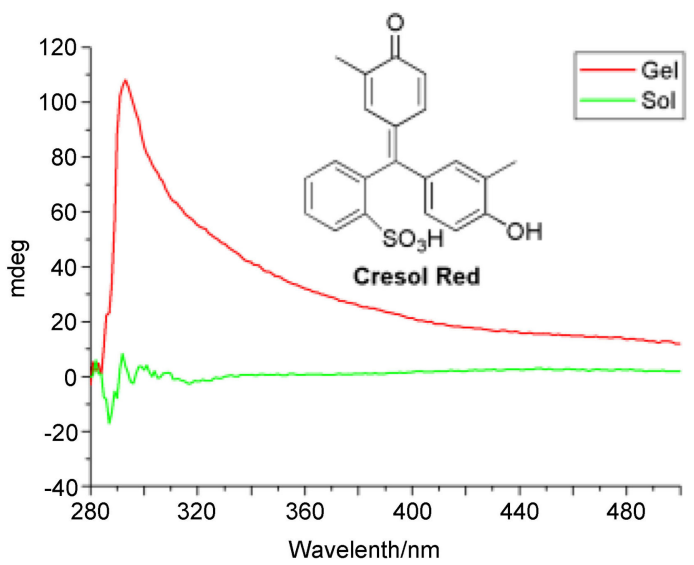

图 1223 诱导甲酚红产生超分子手性信号 ${ }^{[44]}$

Figure 12 CD spectra signal of cresol red induced by $\mathbf{2 3}^{[44]}$

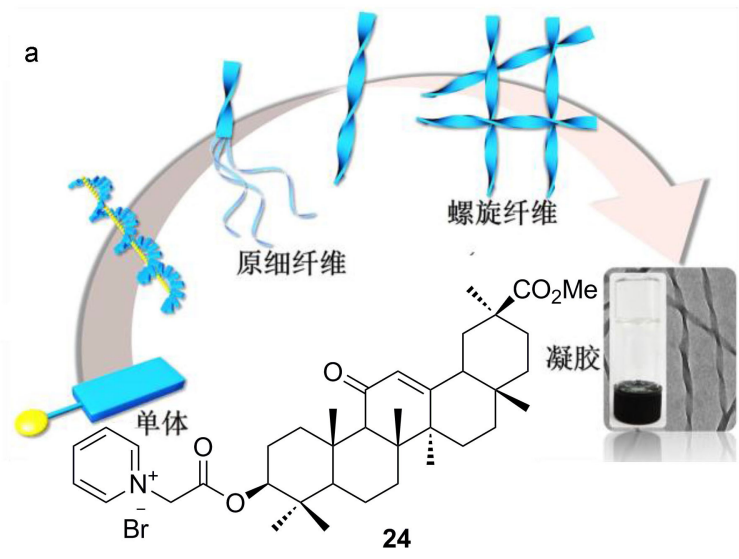

b

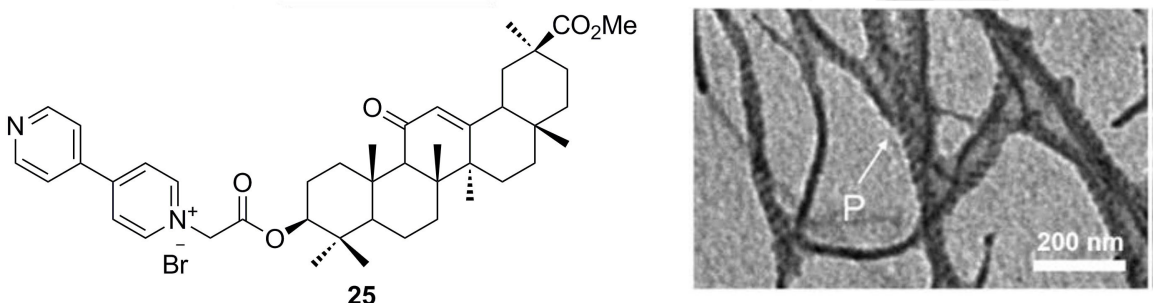

c

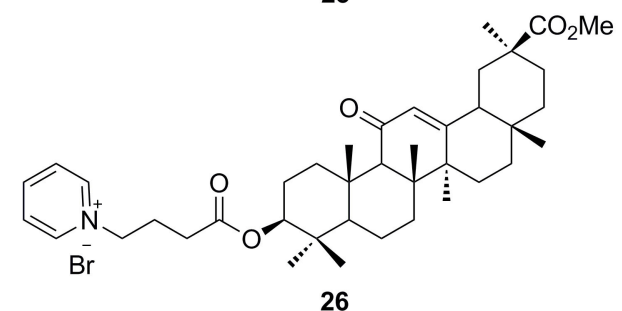

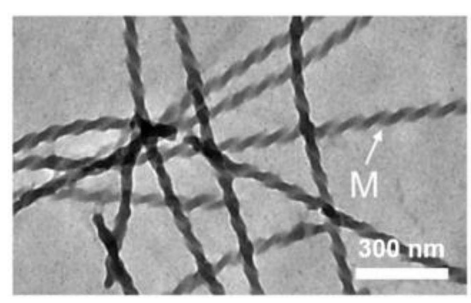

d

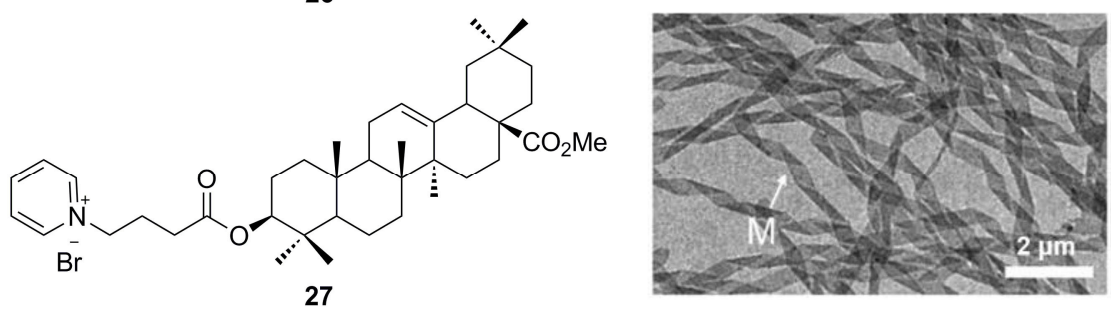

图 13 三萜-吡啶盐分子 $24 \sim 27$ 形成的螺旋组装体 ${ }^{[45]}$

Figure 13 Helical assemblies constructed by triterpenoid-pyridinium $\mathbf{2 4} \sim \mathbf{2} 7^{[45]}$ 


\section{2 非手性基元在手性因素诱导下的超分子手性组装}

在手性因素诱导非手性基元发生自组装时，手性不 再源自基元自身, 通常来自外加的手性分子或手性物理 外场. 其中, 手性分子作为手性源的报道最为广泛, 它 们借助分子间相互作用, 将自身的不对称因素传递至非 手性基元, 使非手性基元发生手性排列, 产生超分子手 性信号 ${ }^{[46-47]}$. 在分子设计时, 手性诱导源往往与非手性 基元具有相似的结构, 以便参与组装并形成共组装体, 从而推动手性传递过程. 值得注意的是, 极少量的手性 分子往往足以诱导非手性基元整体的手性组装, 使手性 信号以非线性的形式放大, 称为 “将军-士兵” 效 应 ${ }^{[48-49]}$. 此概念被 Green 等 ${ }^{[50]}$ 在 1989 年首次提出: 他们 在正己基异氧酸酯单体聚合时掺入少量手性 $S-2,2$ 二二甲 基-1,3-二氧杂环-4-亚甲基异氧酸酯单体, 发现共聚物 表现出强烈的 $\mathrm{CD}$ 信号. 当手性单体摩尔分数为 $1 \%$ 时, 共聚物的手性信号强度仅比完全由手性单体构成的聚 合物弱一半, 说明手性单体能控制与之协同组装的大量 非手性单体的排列, 就如同将军指挥麾下大批士兵, 因 此 Green 等将该类手性放大现象称为 “将军-士兵” 效 应.

Meijer 课题组 ${ }^{[1-52]}$ 对超分子体系中的手性放大现象 进行了深入研究, 借助 “将军-士兵” 效应成功实现手 性分子诱导的超分子手性自组装. 他们以均苯三甲酸为 核, 设计合成具有 $C_{3}$ 对称性的平面型分子 28 和 29 (图 14 ), 分子结构中的苯环在组装时提供 $\pi-\pi$ 作用, 大量的 酰胺键则能提供丰富的氢键位点. 非手性分子 $\mathbf{2 8}$ 在正 十二烷中形成的组装体不具有 $\mathrm{CD}$ 信号, 而向其掺杂少

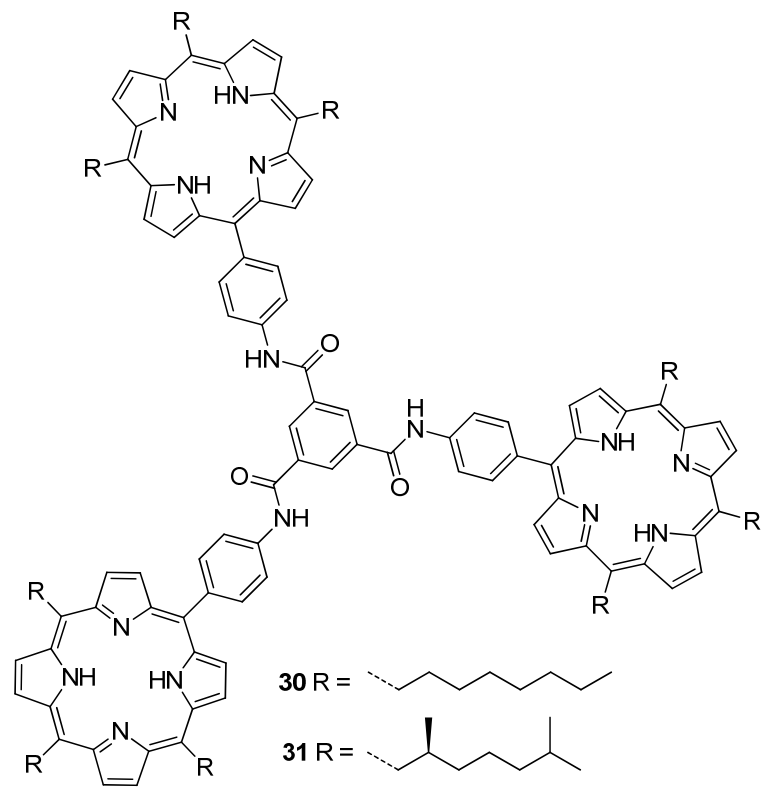

量手性分子 29 后则可以诱导组装体发生手性排列，表 达出 $\mathrm{CD}$ 信号. 当掺杂比例为 $1 / 80$ 时, CD 信号达到峰值, 与 29 自身手性组装体的 $\mathrm{CD}$ 信号相当. 表明一个手性分 子 29 通过非共价作用能够将其手性传递至 80 个非手性 分子 28, 形成有序的超分子手性组装体.

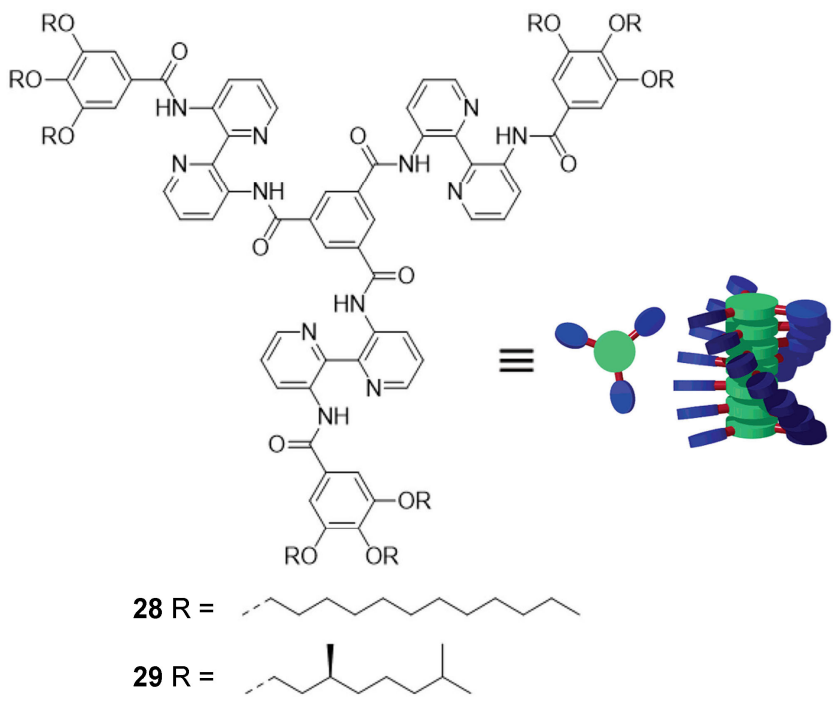

图 $14 C_{3}$ 对称性分子 $\mathbf{2 8}$ 和 $\mathbf{2 9}$ 的化学结构和螺旋组装示意 图 $^{[51]}$

Figure 14 Chemical structures of $C_{3}$-symmetrical 28 and $\mathbf{2 9}$, and illustration of their helical assemblies ${ }^{[51]}$

Elemans 课题组 ${ }^{[53]}$ 在运用 “将军一士兵” 效应诱导 非手性基元进行手性组装时，发现溶剂类型显著影响组 装过程. 卟啉修饰的均苯三甲酰胺非手性基元 $\mathbf{3 0}$ 与相 似结构的手性分子 31 进行共组装, 组装体在正庚烷和 甲苯两种溶剂中表现出完全不同的超分子手性(图 15).

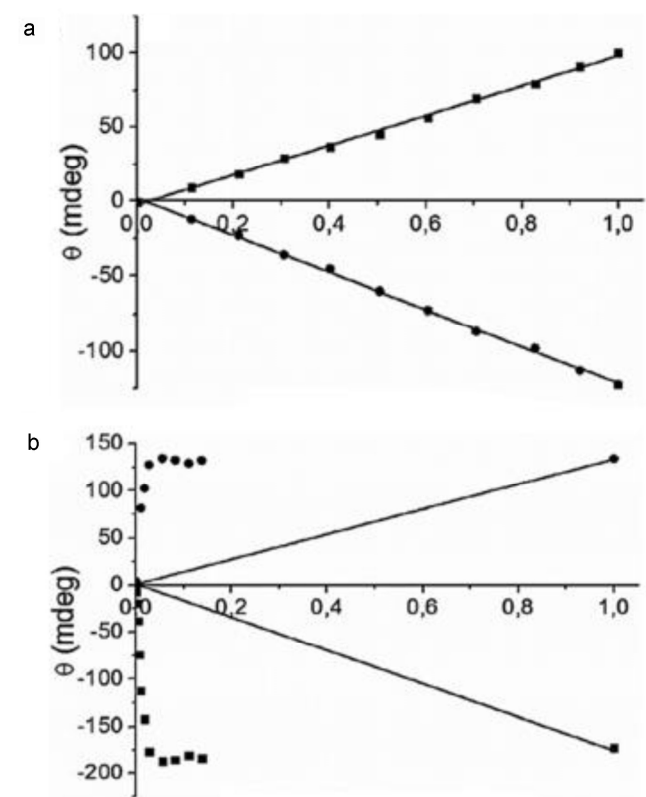

图 1530,31 的化学结构式与共组装体 $\mathrm{CD}$ 信号随 31 比例在(a)正庚烷和(b)甲苯中的变化 ${ }^{[53]}$

Figure 15 Chemical structures of 30, 31 and CD spectra of co-assemblies at different ratio of $\mathbf{3 1}$ in (a) $n$-heptane and (b) toluene ${ }^{[53]}$ 
在正庚烷中, 共组装体的 $\mathrm{CD}$ 信号随 $\mathbf{3 1}$ 的比例提高 而线性增长, 表明二者之间不存在手性诱导过程. 而在 甲苯溶剂中, 当 31 的摩尔分数仅有 $2.5 \%$ 时, 共组装体 的 $\mathrm{CD}$ 信号与完全由 $\mathbf{3 1}$ 构成的手性组装体相当, 存在显 著的 “将军-士兵” 效应. 导致这种结果的原因是：在 酰胺键的氢键和卟啉环的强 $\pi-\pi$ 作用下分子在正庚烷中 紧密堆积, 组装体稳定, 难以进行动态分子交换, 手性 分子无法有效诱导非手性基元产生手性排列. 该研究表
明在利用 “将军一士兵” 效应构建超分子手性组装体时, 选择合适溶剂的重要性.

赵新等 ${ }^{[54]}$ 发现通过苯丙氨酸衍生物 $\boldsymbol{D} / \boldsymbol{L}-\mathbf{3 2}$ 、甘氨酸 衍生物 33 诱导苯并菲衍生物 34 的超分子手性时，“将 军-士兵” 效应和 “多数” 效应同时存在(图 16). 质子 化的氨基能够作为氢键受体与非手性分子 $\mathbf{3 4}$ 中多个 $\mathrm{N}$ 原子形成多重氢键，使手性从 $\boldsymbol{D} / \boldsymbol{L}-\mathbf{3 2}$ 的 $\alpha$ 碳原子传递至 34 的吡啶基中, 形成螺旋桨型排列(图 16a). 当 $\boldsymbol{D}$-32 和 (a)<smiles>CCOC(=O)[C@@H]([NH3+])Cc1ccccc1</smiles><smiles>CCOC(=O)C(Cc1ccccc1)N[N+]([O-])([O-])[O-]</smiles>
L-32<smiles></smiles>

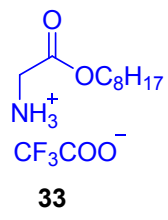

33

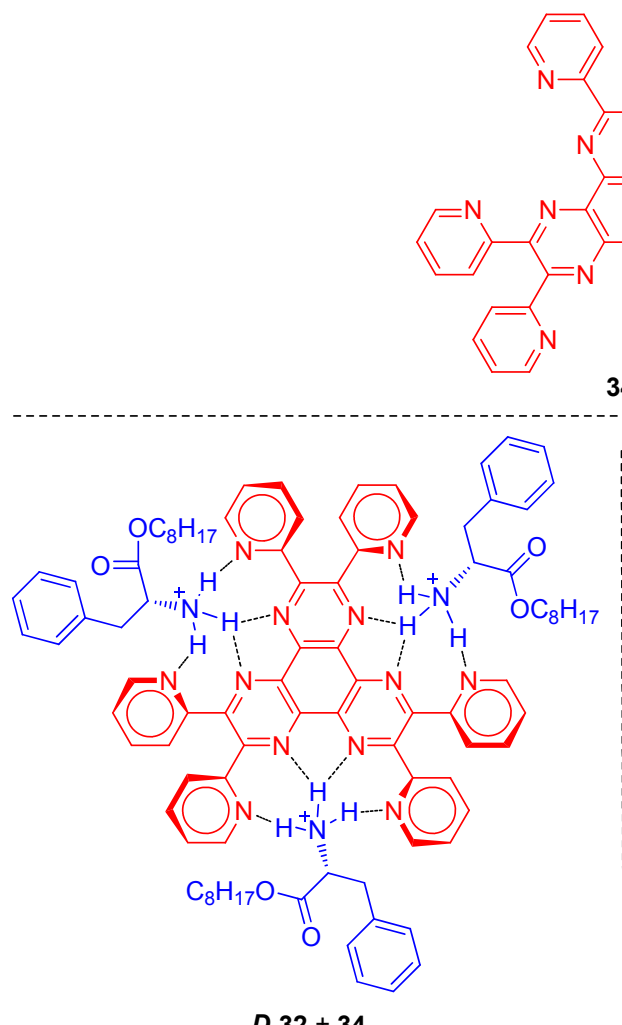

$D-32+34$

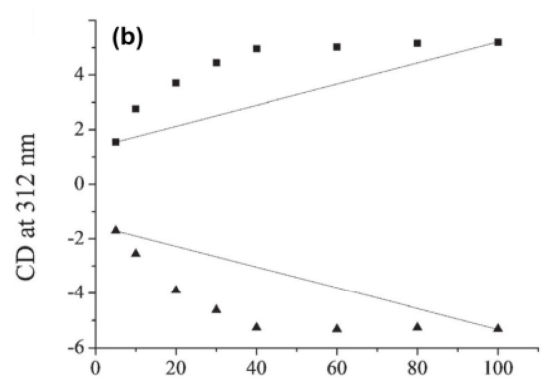

Mole fraction of $D / L-32$ in mixed $D / L-32$ and 33

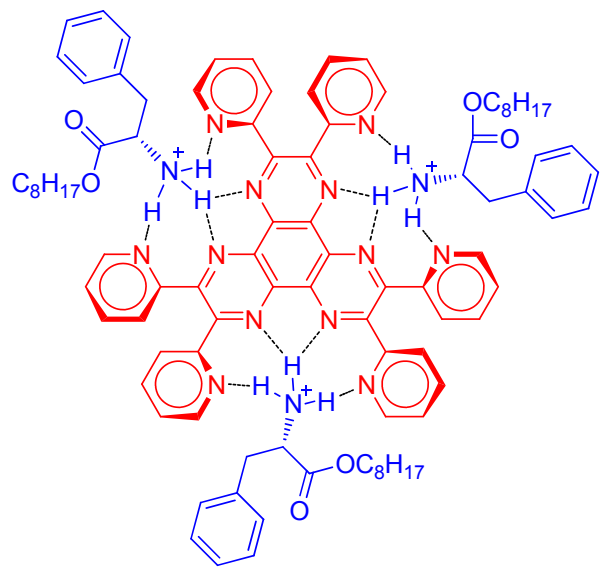

$L-32+34$

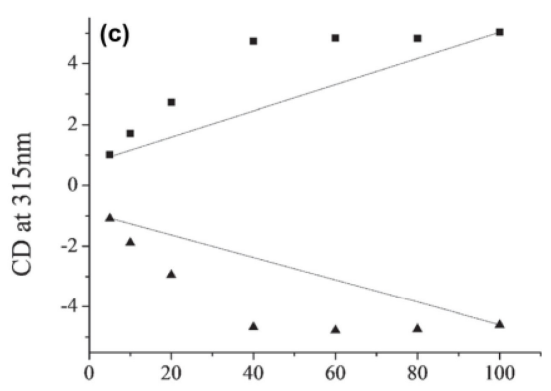

Enantiomeric excess of mixed $D / L-32$

图 16 (a) $D / L-32,33,34$ 及 $D / L-32$ 与 34 形成手性复合物的化学结构、 (b) CD 信号随 $D / L-32$ 与 33 混合物中 $D / L-32$ 比例的变化(

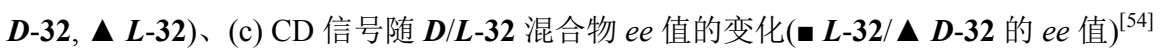

Figure 16 (a) Chemical structures of $\boldsymbol{D} / \boldsymbol{L}-\mathbf{3 2}, \mathbf{3 3}, \mathbf{3 4}$ and the chiral complexes of $\boldsymbol{D}$-32 $+\mathbf{3 4}$ and $\boldsymbol{L}-\mathbf{3 2}+\mathbf{3 4}$, (b) CD spectra versus different molar fractions of $\boldsymbol{D} / \mathbf{L}-\mathbf{3 2}$ in the mixtures of $\boldsymbol{D} / \boldsymbol{L}-\mathbf{3 2}$ and $\mathbf{3 4}(\boldsymbol{D} \mathbf{- 3 2}, \boldsymbol{\Delta} \mathbf{L}-\mathbf{3 2})$, and (c) plot of CD intensity at $315 \mathrm{~nm}$ versus different $e e$ values of mixed $\boldsymbol{D} / \boldsymbol{L}-\mathbf{3 2}(\square e e \text { of } \boldsymbol{L}-\mathbf{3 2}, \boldsymbol{\Delta} e e \text { of } \boldsymbol{D}-\mathbf{3 2})^{[54]}$ 
33 混合物作为氢键受体时，“将军-士兵” 效应使复合 物的 CD 信号随 $\boldsymbol{D}-\mathbf{3 2}$ 比例非线性增加, 摩尔分数为 $40 \%$ 的手性分子足以诱导整体的超分子手性, $\boldsymbol{L}-\mathbf{3 2}$ 也具有相 同现象(图 16b). 当 $\boldsymbol{D}-32$ 和 $\boldsymbol{L - 3 2}$ 混合进行手性诱导时, $\mathrm{CD}$ 信号随 $e e$ 值增加也表现出非线性增加, 体现出 “多 数” 规则决定的超分子手性(图 16c).

“将军-士兵” 效应在天然生物分子中同样存在: Kaczor 和 Baranska 等 ${ }^{[55]}$ 发现从胡萝卜根部细胞提取的 类胡萝卜素微晶具有螺旋结构, 但微晶成分的摩尔分数 为 95\%的是非手性 $\beta$-胡萝卜素 35(图 17). 他们使用手性 $\alpha$-胡萝卜素 36 和虾青素 37 , 将它们与 35 的共组装体作 为模型, 证明手性能够通过 $\pi-\pi$ 作用在类胡萝卜素的聚 集体中进行传递与放大. 为了避免类胡萝卜素结构相似 性带来的谱图重叠问题, 他们巧妙地将 35 部分氝代, 在 共组装体中直接检测到気代 35 的偏振拉曼信号, 进一 步证实手性传递的发生. 由于 $\beta$-胡萝卜素与 $\alpha$-胡夢卜素 在细胞内共存, 因此前者在后者的诱导下形成手性微晶 结构.

除手性分子外，人们受启发于手性物理外场下的不 对称合成 ${ }^{[56]}$, 成功地将手性从圆偏振光、磁光组合场、 涡流场等 ${ }^{[57-59]}$ 物理外场传递到非手性基元. 其中, 将圆 偏振光作为手性外场的报道较多. 一方面是因为有机化 合物中常具有三苯胺、丁二炔、偶氮苯等光响应基团, 另
一方面是因为圆偏振光被认为是生物分子手性的起源 之一 ${ }^{[60]}$. 相关研究不仅为超分子手性组装体的构建提 供了新方法, 还对认识自然界手性环境的起源具有重要 意义.

$\operatorname{Kim}$ 课题组 $^{[61]}$ 利用圆偏振光调控了非手性基元三 苯胺衍生物 38 的超分子手性组装行为(图 18). 在氯代溶 剂如 1,2-二氯乙烷中组装时, 38 在光激发下形成三苯胺 正离子自由基，分子平面化使 $\pi-\pi$ 作用更加有效，形成 紧密堆积的组装体. 外界圆偏振光诱导 $\mathbf{3 8}$ 在 $\pi$ 电子激发 过程中发生分子平面的微小扭曲, 在层层堆积过程中被 不断放大，最终形成具有手性结构的超分子组装体. 此 外, 体系的超分子手性与光的圆偏振方向相同: 左旋圆 偏振光 $(L-C P L)$ 使组装体形成左螺旋, 右旋圆偏振光 $(R-C P L)$ 使组装体形成右螺旋, 且二者可以通过辐照相 反偏振方向的光相互转化. 由于 38 中的三个丁二炔臂 在紫外光下会光聚合, 形成共价键连接的共轭结构, 因 此作者通过左/右旋的圆偏振紫外光 $(L / R-C P U L)$ 成功固 定组装体的超分子手性, 并使组装体具有导电性, 有望 应用于手性传感器领域.

Fujiki 等 ${ }^{[62]}$ 发现手性从圆偏振光到非手性分子的传 递不仅与圆偏振光的手性有关，还与波长有密不可分. 当偶氮苯侧链型高分子 39 发生手性聚集排列时, 双信 号的 Cotton 效应峰出现在 390 (峰 1) 和 $310 \mathrm{~nm}$ 处(峰 2),<smiles>CC1=CCCC(C)(C)C1/C=C/C(C)=C/C=C/C(C)=C/C=C/C=C(C)/C=C/C=C(C)/C=C/C1=C(C)CCCC1(C)C</smiles>

35<smiles>CC1=C(/C=C/C(C)=C/C=C/C=C(C)/C=C/C=C(C)/C=C/C2=C(C)C(C)(C)C[C@H](O)C2=O)C(C)(C)C[C@H](O)C1=O</smiles>

图 17 类胡萝卜素 $35 \sim 37$ 的化学结构 ${ }^{[55]}$

Figure 17 Chemical structures of carotenoids $35 \sim 37^{[55]}$<smiles>[R]C(=O)Nc1ccc(N(c2ccc(NC([R])=O)cc2)c2ccc(NC([R])=O)cc2)cc1</smiles>
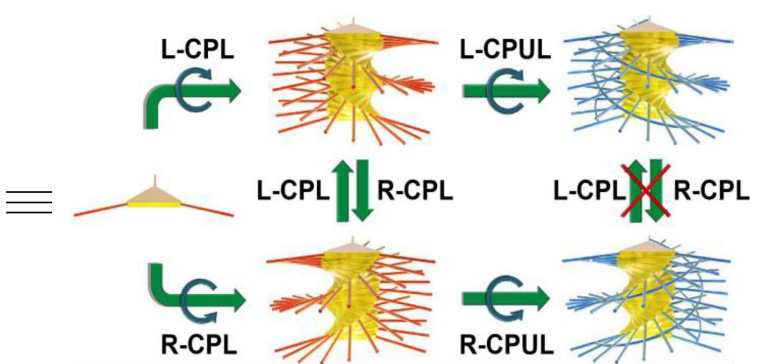

38

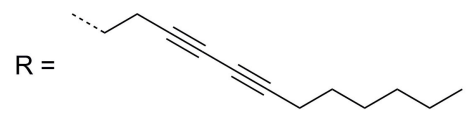

图 18 圆偏振光调控 $\mathbf{3 8}$ 的超分子手性组装 ${ }^{[61]}$

Figure 18 Manipulation of supramolecular chiral assembly of $\mathbf{3 8}$ by circularly polarized light ${ }^{[61]}$ 
对应偶氮苯的 $\pi-\pi *$ 的跃迁. 如果使用 $\pi-\pi *$ 跃迁波长范围 外的圆偏振光作为手性源, 手性诱导过程将不能发生. 当使用 $\pi-\pi$ *跃迁波长范围内的圆偏振光作为手性源时, 根据波长归属可将偶氮苯 $\pi-\pi$ *跃迁的激发光分为两组. 这两组激发光在手性诱导过程中表现出相反的趋势: 即 使手性相同, 365 (属于峰 1 范围)和 $313 \mathrm{~nm}$ (属于峰 2 范 围)的圆偏振光在诱导 39 手性组装时, 组装体 $\mathrm{CD}$ 信号 峰相反(图 19). 手性诱导的原理是: 圆偏振光的扭矩使 具有光各向异性的偶氮苯聚集体采取某一方向的螺旋 $\pi-\pi$ 堆积, 在不同波长光下激发的偶氮苯精细能级结构 不同, 受到圆偏振光的扭矩方向不同, 从而表现出不一 样的超分子手性特征.

Ribó 课题组 ${ }^{[63]}$ 在利用浴流控制组装体超分子手性 方面进行了开创性的工作. 他们发现旋转蒸发仪的顺逆 时针转动引发的涡流, 可以控制磺酸苯基取代的卟啉分 子 40 的超分子手性组装. 在 Ribo 课题组的研究基础上, Scolaro 等 ${ }^{[64]}$ 向非手性基元 $\mathbf{4 0}$ 的组装体系中额外引入磁 场, 发现涡流场、磁场和重力场三种物理外场均对组装 体的超分子手性具有影响. 在没有磁场时, 旋转浴流和 重力无法有效诱导 40 形成超分子手性组装体. 由于 $\mathbf{4 0}$ 在不同轴向的磁化率不同, 磁场能够诱导 $\mathbf{4 0}$ 的取向排 列, 使浴流与有效重力(磁力与重力的组合)成功诱导组 装体的超分子手性. 手性的方向由浴流角动量 $L$ 与有效 重力 $G_{\mathrm{eff}}$ 的方向共同决定, 平行的 $L$ 与 $G_{\mathrm{eff}}$ 诱导组装体 形成左手螺旋, 反平行的 $L$ 与 $G_{\mathrm{eff}}$ 诱导组装体形成右手 螺旋(图 20). 手性信号的强度受磁场强度 $B$ 、有效重力 $G_{\text {eff }}$ 的数值影响, 与 $B^{2} / G_{\text {eff }}$ 值表现出一定程度的线性关
系, 有望通过磁场实现对组装体超分子手性特征的精细 调控.

手性因素诱导非手性基元组装为超分子手性组装 体的构建提供了新思路，极大丰富了基元类型. 借助手 性传递与放大的过程，该构筑方式还能方便确定一些无 发色团的手性分子的绝对构型 ${ }^{[65]}$. 由于利用该方法制 备的组装体手性与手性因素关系密切, 因此人们可以通 过改变 “将军” 分子或物理外场的手性灵活调控超分 子手性，使同一种非手性基元形成的组装体表达出相反 的超分子手性，显著提高这类组装体在不同应用领域的 普适性.

\section{3 非手性基元在对称性破缺效应下的超分子手性组 装}

对称性破缺是指非手性物质在无外界手性因素诱 导下自发形成手性结构的过程，广泛存在于亚原子水平 到生物圈的各个尺度 ${ }^{[6]}$. 在超分子化学中, 对称性破缺 能有效诱导非手性基元产生超分子手性：非手性基元间 由于空间阻碍等因素不能完全重合堆积时, 就会以扭曲 的方式错位排列，沿着相同的扭曲方向不断聚集，形成 长程有序的螺旋构象, 表现出超分子手性 ${ }^{[67]}$. 由对称性 破缺产生的超分子手性是随机的，在统计学上相反手性 的两种组装体会等概率出现，形成超分子水平上的外消 旋体，极大限制这类体系的实际应用. 但与此同时，对 称性破缺现象被认为在手性起源中发挥了重要作用, 超 分子化学家进行了大量的相关研究, 希望以此解开手性 起源的谜题 ${ }^{68]}$.
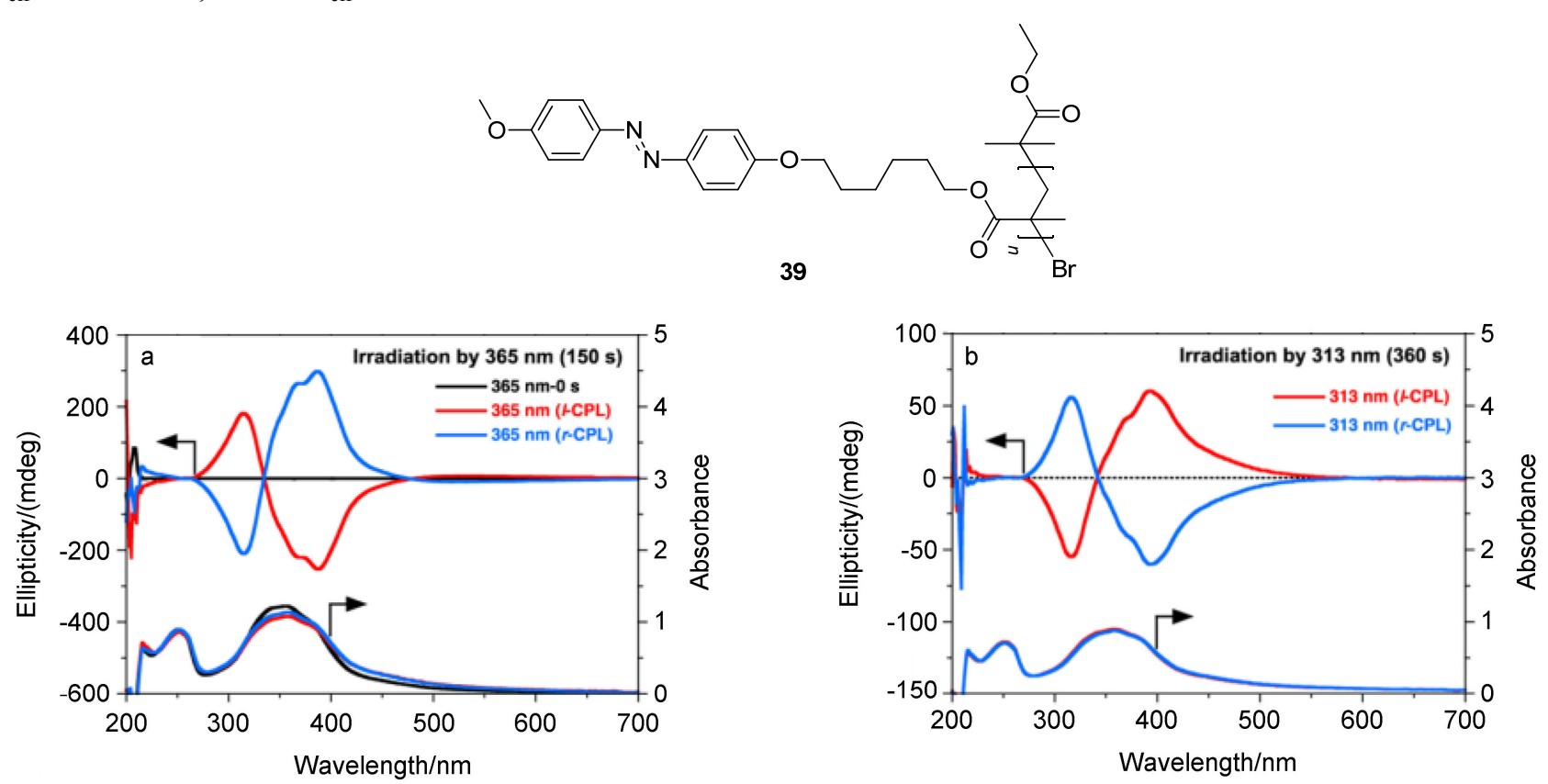

图 1939 的化学结构式及其组装体在两种波长圆偏振光诱导下产生的 $\mathrm{CD}$ 信号(a) $365 \mathrm{~nm}$ (b) $313 \mathrm{~nm}^{[62]}$

Figure 19 Chemical structure of $\mathbf{3 9}$ and CD spectra of chiral assemblies of $\mathbf{3 9}$ induced by CPL at (a) $365 \mathrm{~nm}$ (b) $313 \mathrm{~nm}^{[62]}$ 

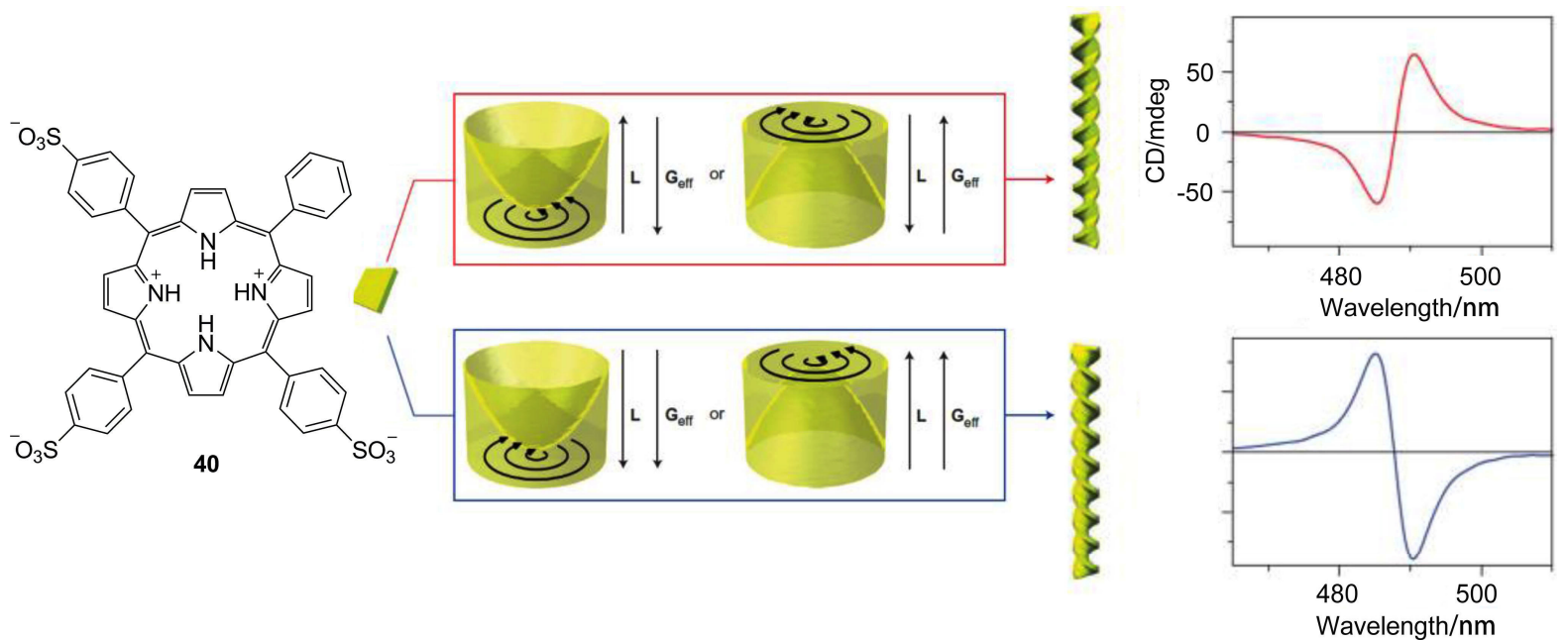

图 2040 的化学结构式及涡流和有效重力对 40 组装体的手性诱导 ${ }^{[64]}$

Figure 20 Chemical structure of $\mathbf{4 0}$ and supramolecular chirality of assembled $\mathbf{4 0}$ induced by vortex and efficient gravity ${ }^{[64]}$

在二维界面上非手性基元处于受限空间环境内, 堆 积排列方式受限, 更容易出现对称性破缺现象而形成超 分子手性组装体. 自 Zasadzinski 等 ${ }^{[69]}$ 在 1994 年报道 Langmuir-Blodgett 膜中正二十烷酸的对称性破缺组装 后, 界面组装中的对称性破缺现象得到了广泛研究. 刘 鸣华课题组 ${ }^{[70]}$ 发现长烷基链缀合的非手性芸并咪唑 41 能在硝酸银溶液-空气界面上组装形成手性 LB 膜. 在银 离子与咪唑的金属配体作用驱动下, 41 在界面处形成线 性组装体. 为避免菜基团在聚集时的空间位阻, 相邻分 子间存在夹角, 使组装体表现出超分子螺旋手性(图 21). 如果 41 与硝酸银不是在界面处发生配位, 而是在体相 中配位后再成膜, 则无法表现出手性特征, 证明受限空 间对体系发生对称性破缺的必要性.

相比于受限二维界面, 分子在三维体相中的自由度 更高, 对称性破缺相对较难发生. 但人们研究发现非手 性的平面 $C_{3}$ 对称性分子是一类优良的对称性破缺型组 装基元. 在多种非共价键的协同下, 它们往往采取紧密 堆积的方式, 受基元侧臂空间位阻、静电排斥等作用扭 曲排列, 形成超分子手性螺旋 ${ }^{[71-72]}$. Hud 等 ${ }^{[73]}$ 巧妙地利 用核苷类似物 42 与三聚氧酸衍生物 43 两种非手性分子 构建了一个平面 $C_{3}$ 对称性基元, 42 与 $\mathbf{4 3}$ 间的氢键互补 性使它们形成六聚体(图 22a), 六聚体在疏水作用驱动 下组装形成螺旋纤维. 在纤维手性的监测中发现: $\mathrm{CD}$ 信 号是随机的, 既无稳定的正负性, 也没有稳定的信号值 (图 22b), 表明该体系是典型的对称性破缺导致的超分 子手性组装体. 手性产生的原因可能是 43 的负电荷末 端在堆积时相互排斥, 导致六聚体在组装过程中彼此错 开一定的角度, 以螺旋结构进行排列.

此外, 刘鸣华课题组 ${ }^{[74]}$ 发现 $C_{3}$ 对称性分子 44 能形 成对称性破缺型的手性凝胶, 手性溶剂可以对原本随机

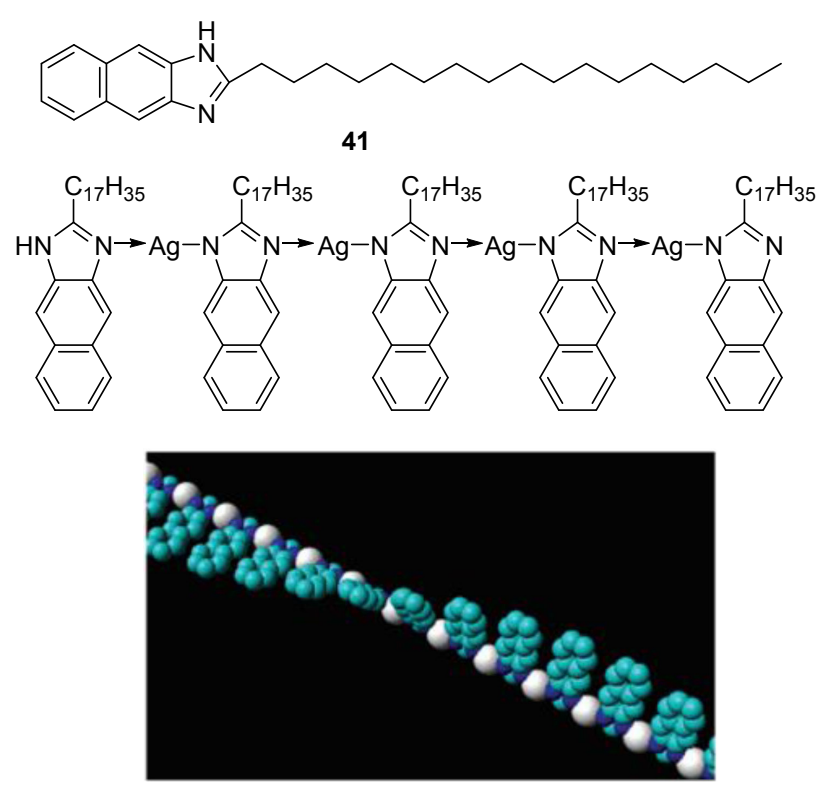

图 2141 的化学结构式及其与 $\operatorname{Ag}(\mathrm{I})$ 的手性组装模型 [70]

Figure 21 Chemical structure of $\mathbf{4 1}$ and the proposed chiral model of 41-Ag(I) ${ }^{[70]}$

产生的手性进行调控. 由于肉桂酸臂的空间位阻, 44 在 组装时随机产生左旋或右旋聚集体，因此在凝胶微观结 构中同时存在两种方向的螺旋纤维. 当向凝胶体系中引 入少量手性溶剂时，如 $R / S$-松油烯-4-醇，可以通过 “将 军一士兵” 效应诱导基元形成单一手性的组装体, 并且 具有手性记忆，即在手性溶剂被除去后仍保持手性特征 (图 23). 这是首例组装基元间仅存在弱 $\pi-\pi$ 作用，仍能 发生对称性破缺超分子手性组装的报道.

基元的 “平面性” 和 “侧臂互斥性” 在对称性破 缺中发挥着重要作用, 具有此类特征的基元即使不是 $C_{3}$ 结构, 也往往能发生对称性破缺型手性组装. 例如, Tschierske 课题组 ${ }^{[75]}$ 合成的寡聚乙二醇修饰的 4-苯基- 
(a)<smiles>Nc1cc(N)nc(N)n1</smiles>

42<smiles>O=C(O)CCCCCn1c(=O)[nH]c(=O)[nH]c1=O</smiles>

43

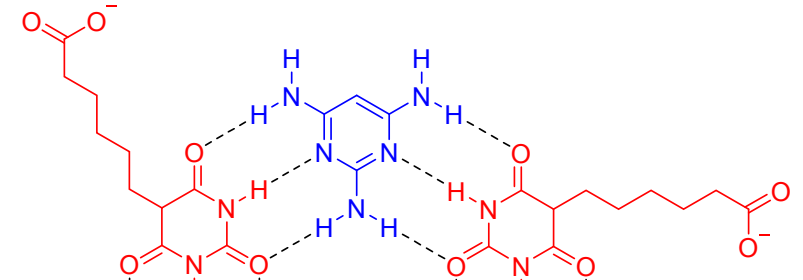

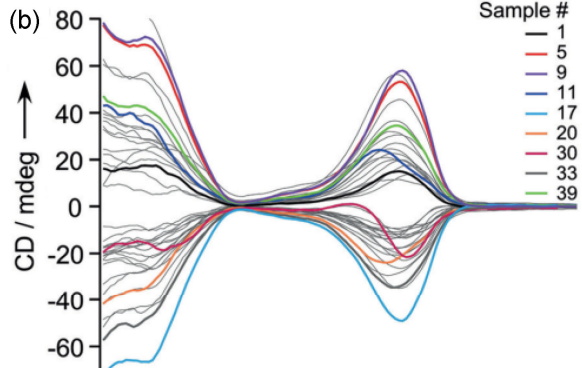

图 22 (a) 42, 43 及其六聚体的化学结构以及(b) 40 份独立测试中组装体的 CD 信号 ${ }^{[73]}$

Figure 22 (a) Chemical structures of $\mathbf{4 2 , 4 3}$ and their hexamer, and (b) CD spectra of 40 independent assemblies ${ }^{[73]}$

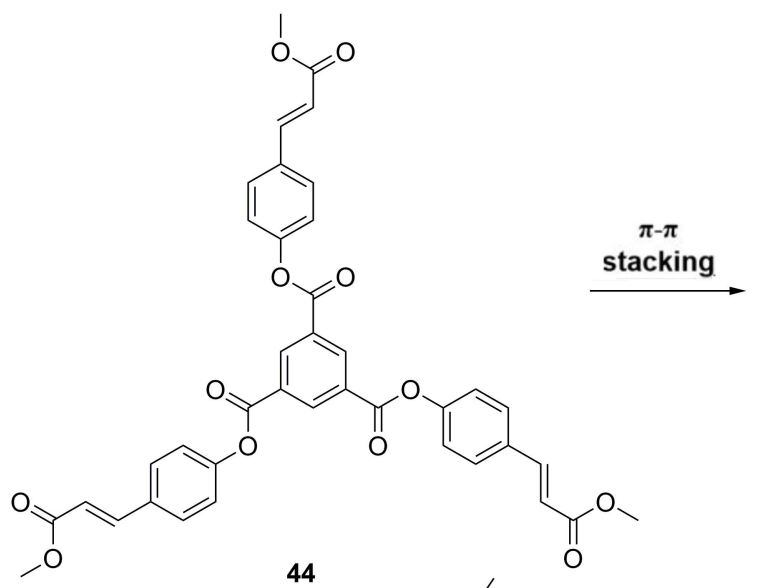

44
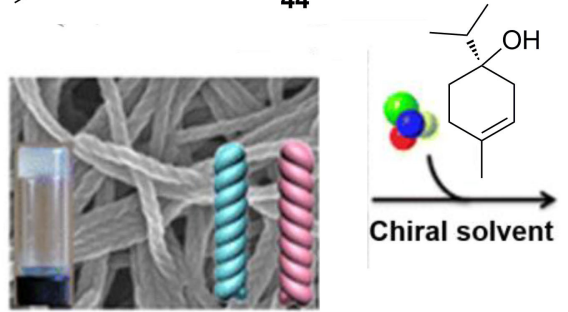

Chiral solvent

Symmetry breaking

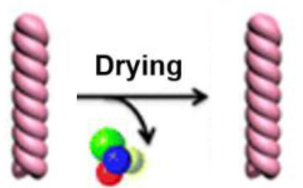

\section{Chiral induction Chiral memory}

图 2344 的化学结构及其凝胶对称性破缺、手性诱导与手性 记忆的示意图 ${ }^{[74]}$

Figure 23 Chemical structure of $\mathbf{4 4}$ and illustration of symmetry breaking, chiral induction and chiral memory of $\mathbf{4 4}$ ge $^{[74]}$

2,6-二氨基-1,3,5-三嗪 45 和 46, 在氢键诱导下头对头二
聚形成 $C_{2}$ 对称性基元. 由于寡聚乙二醇臂的空间位阻, 二聚体在后续堆积过程中产生螺旋扭曲, 得到对称性破 缺的手性组装体(图 24a), 其原理与上述 $\mathrm{C}_{3}$ 分子相似.

(a)
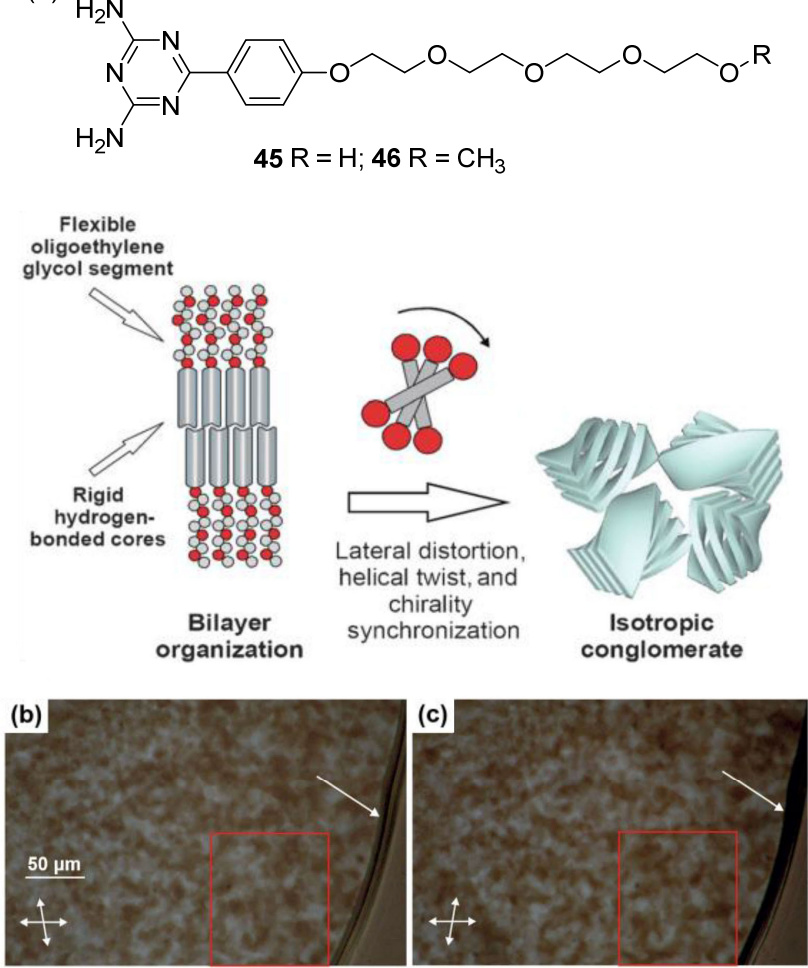

图 24 (a) 45 和 46 的化学结构及其手性组装示意图, 以及(b, c)组装体中相反手性(明暗)的结构域 ${ }^{[75]}$

Figure 24 (a) Chemical structures of 45,46 and illustration of their chiral assemblies, and (b, c) chiral domains with opposite handedness (bright/dark) in assemblies ${ }^{[75]}$ 
由于 45 和 46 的螺旋堆积长程手性同步, 可以在偏 光显微镜下观察到堆晶中的手性分区. 如图 $24 \mathrm{~b}$ 和 $24 \mathrm{c}$ 所示, 在偏光片旋转 $90^{\circ}$ 后, 晶体结构中的亮部变为暗 部、暗部变为亮部, 说明偏振光在不同晶体区域中被旋 转到了相反方向. 这是首次在宏观水平观察到非手性分 子在各向同性堆晶结构中的对称性破缺现象.

目前构建对称性破缺型超分子手性组装体已有较 为完善的方法，人们能通过同一基元简单地制备两种互 为镜像、超分子手性相反的组装体, 有望在双向圆偏振 发光等领域发挥价值. 但体系中出现哪一种手性结构完 全是随机的. 在实际应用的要求下, 人们往往还需要额 外引入手性源, 才能获得期望的单一手性组装体. 故这 类体系的开发与应用受到极大限制, 利用对称性破缺制 备功能性的手性组装体将成为研究目标.

\section{4 小结}

尽管根据上述三种方法构建超分子手性组装体的 策略已经基本成熟, 通过各类非共价相互作用也可以对 组装基元的聚集模式进行推算模拟, 但基元结构对超分 子手性的影响仍难以预测. 对于第一类手性基元构建的 超分子手性组装体, 基元构成简单, 环境变量少, 分子 手性在控制组装体的超分子手性时起重要作用, 开发与 应用较为便捷, 能作为研究基石帮助人们由简入繁、由 浅入深地理解分子结构与超分子手性之间的关系. 第二 种构建方法通过引入手性分子或手性物理外场使非手 性基元产生超分子手性，所得组装体结构具有更好的可 调性, 在光学、电学和生物效应等方面表现出更加优异 的性能 ${ }^{[76]}$. 同时, 通过分析这类组装体中手性在物理量 与分子之间、分子与分子之间的传递，人们能够对手性 起源与发展过程进行模拟分析. 而在第三类对称性破缺 导致的手性组装中, 超分子手性的产生是分子间相互作 用引起错位堆积的结果, 在统计波动下表现出超分子手 性, 存在一定程度的偶然性, 极大限制实际应用. 进一 步探索诱导该体系产生单一超分子手性的相关规律, 有 望解答生物体内同手性化学环境产生的原因.

\section{3 超分子手性组装体的应用}

超分子手性组装体的研究价值不仅在于它为人们 提供了一个模拟自然界手性现象的工具, 帮助理解手性 起源, 更重要的是提供了一个结构多样、性质可调的软 物质平台. 随着越来越多组装体手性功能的开发, 它们 已经被广泛应用于手性模板、手性识别、圆偏振发光和 不对称催化等领域.

\section{1 手性模板}

超分子手性组装体具有多样的纳米结构, 能够作为
多种无机材料和有机一无机杂化材料的合成模板，实现 手性形貌的直接复刻 [77]. 在形貌复刻过程中, 组装体模 板与材料前体间的分子间相互作用发挥着关键作用: 它 们是手性从组装体传递至材料前体的媒介, 诱导前体发 生手性排列, 逐步生长成手性纳米材料. Stupp 等 ${ }^{[78]}$ 在 2002 年首次将组装体的手性特征转录到纳米材料中. 他们设计的螺旋带组装体具有两亲性, 亲水侧比疏水侧 对 $\mathrm{Cd}^{2+}$ 的亲和力更强, 诱导 $\mathrm{Cd}^{2+}$ 聚集在螺旋带亲水侧 并结晶生长, 进而得到手性 $\mathrm{CdS}$ 纳米螺旋. 随着相关研 究不断深入, 人们以手性组装体为模板, 成功借助静电 作用、配位作用、氢键等非共价键实现手性转录, 制备 出多种组成和结构的手性纳米材料.

我们课题组 ${ }^{[79]}$ 以三萜化合物的手性组装体为模板, 简单有效地制备了手性二氧化硅材料, 手性的传递过程 依赖组装体与材料前体间的静电吸附. 以齐墩果酸为骨 架的两亲性分子 47 在甲醇/水体系中能够组装形成右手 螺旋纳米带, 四乙氧基硅(TEOS)水解的原硅酸阴离子 在静电作用下会吸附到富含吡啶阳离子的螺旋表面. 这 些硅前体在螺旋带上矿化生长, 使组装体的螺旋手性印 迹在二氧化硅纳米结构中, 即使除去模板, 手性结构依 然能够保持(图 25).

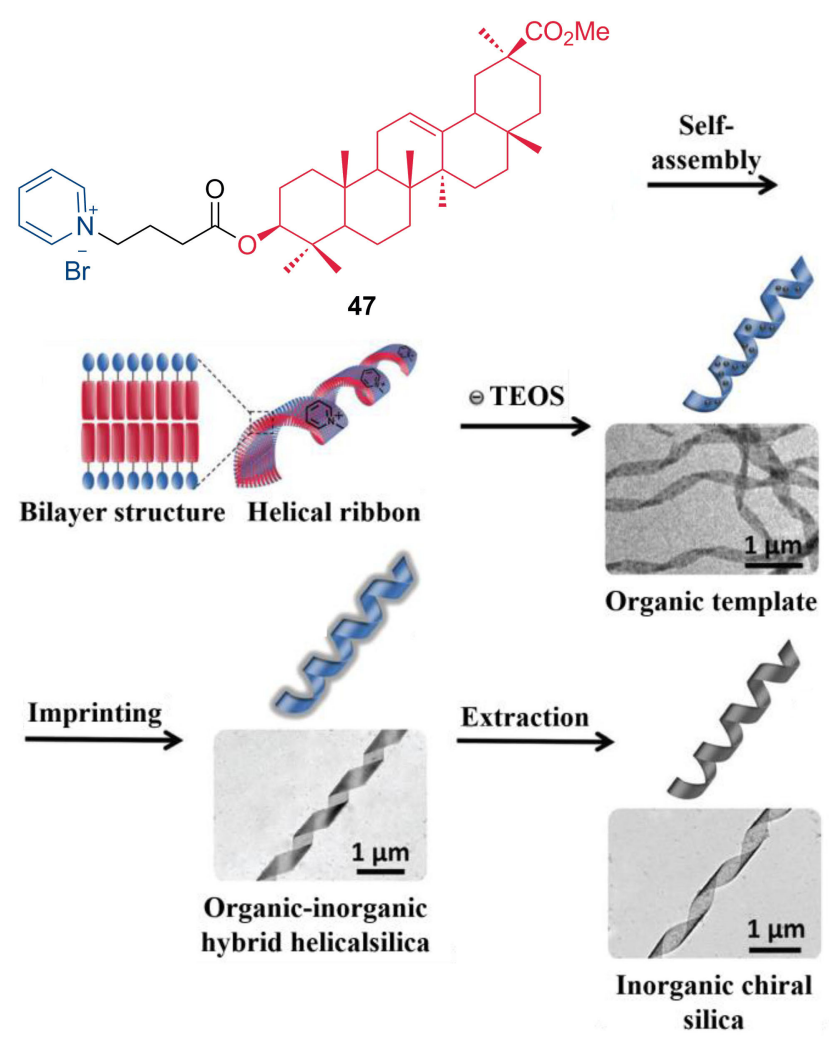

图 2547 的组装过程以及手性从螺旋组装体到无机二氧化硅 的印迹过程示意图 ${ }^{[79]}$

Figure 25 Schematic of self-assembly process of $\mathbf{4 7}$ and chirality imprinting from helical-assembled $\mathbf{4 7}$ to inorganic silica ${ }^{[79]}$ 
Kawai 等 ${ }^{[80}$ 通过超分子手性组装体侧面氨基对纳 米金晶面的吸附, 成功制备手性可控的双螺旋金纳米 线. 手性 12 -羟基硬脂酸 $D / L-48$ 与长链氨基酰胺分子 49 在氯化锂溶液中形成具有夹心结构的螺旋带(图 26). 螺 旋带的超分子手性由 48 分子手性决定: D-48 形成右手 螺旋带, $\boldsymbol{L}-\mathbf{4 8}$ 形成左手螺旋带. 由于 49 末端氨基能够吸 附纳米金的特定晶面，在溶液中原位还原的金颗粒会沿 着螺旋纳米带的侧边生长, 最终形成双螺旋结构的金纳 米线.<smiles>CCCCCCC(O)CCCCCCCCCC(=O)O</smiles><smiles>CCCCCCC(O)CCCCCCCCCC(=O)O</smiles><smiles>CCCCCCCCCCCCCCCCCCCN(CCC(=O)NCCN)CCC(=O)NCCN</smiles>

49

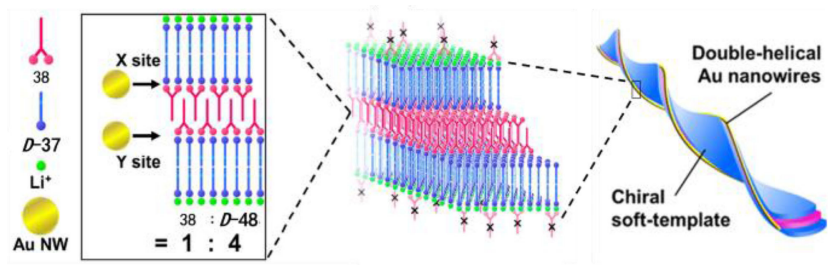

图 $26 D / L-48,49$ 的化学结构及 $D-48$ 与 49 形成螺旋带和双螺 旋金纳米线的结构 ${ }^{[80]}$

Figure 26 Chemical structures of $D / L-48,49$ and supramolecular structures of twisted nanoribbons and double-helical Au nanowires fabricated by $D-48$ and $49^{[80]}$

同样是制备手性金纳米材料, Varghese 等 ${ }^{[1]}$ 则采用 了与上述完全不同的方法: 他们借助两条 DNA 单链的 碱基互补配对使手性传递到纳米金中. 将单链 DNA 修 饰在六苯基苯(HPB)上得到两亲性分子 $\mathbf{5 0}, \mathrm{HPB}$ 基团间 的疏水作用使 50 以双分子层结构形成纳米带. 手性从 单链 DNA 沿共价键传递至 HPB, 诱导 HPB 产生螺旋桨 型的排列, 使纳米带发生扭曲, 最终形成 $M$ 型左手螺旋 组装体. 在纳米金颗粒或棒上修饰互补的另一段单链 DNA 后，在碱基间的多重氢键作用下纳米金吸附在螺 旋纳米带上发生手性排列, 形成一维等离子体手性纳米 材料(图 27).

李广涛课题组 ${ }^{[82]}$ 报道了第一例利用手性组装体模 板构建的手性金属有机框架(MOF)材料. 由于谷氨酸衍
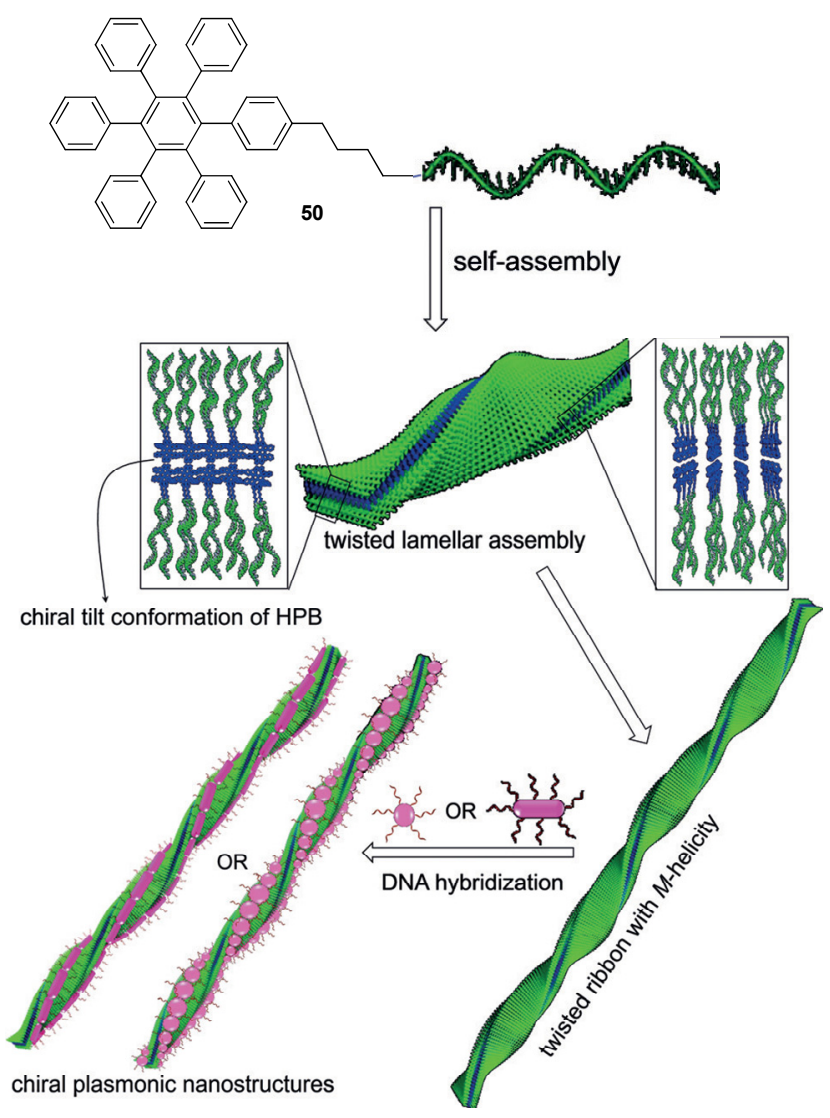

图 27 两亲性分子 $\mathbf{5 0}$ 的自组装及其诱导纳米金颗粒/棒的手 性排列 ${ }^{[81]}$

Figure 27 Self-assembly of amphiphile $\mathbf{5 0}$ and DNA-directed chiral organization of AuNPs and AuNRs ${ }^{[81]}$

生物 $\boldsymbol{D} / \boldsymbol{L}-\mathbf{5 1}$ 在水中可以形成单一手性的螺旋纳米管组 装体，作者利用 $\boldsymbol{D} / \boldsymbol{L}-\mathbf{5 1}$ 中羧基对金属离子的配位作用, 成功将两种 MOF 材料(HKUST-1 和 MIL-100)的前体逐 级生长在组装体表面, 形成具有清晰手性特征的 MOF 材料. 依赖于前体中金属离子的价态特征, $D / L-51$ 组装 体不仅可用于制备螺旋状的 MOF 纳米管，还可以制备 复杂的多螺旋束纳米结构(图 28). 该研究表明同一超分 子手性组装体可以作为多种复杂结构材料的制备模板.

在作为模板制备手性无机和有机一无机杂化材料时, 超分子手性组装体具有良好的空间限域结构, 使产物的 形貌、结构与性能可以精确调控，简化了材料的合成步 骤，为工业化制备提供了可能. 此外，超分子手性组装 体作为一种软模板，一般由有机小分子化合物组成，相 比于由金属氧化物、二氧化硅等构成的硬模板，易于通 过溶解过程去除并回收，降低了制备成本，减少了材料 制备过程中的污染, 符合绿色化学的思想 ${ }^{[83]}$. 但超分子 手性组装体的结构稳定性对温度、 $\mathrm{pH}$ 值等环境因素非 常敏感，限制了它的适用范围。在空间限域性方面，超 分子手性组装体也不如硬模板，手性信息从模板到产物 


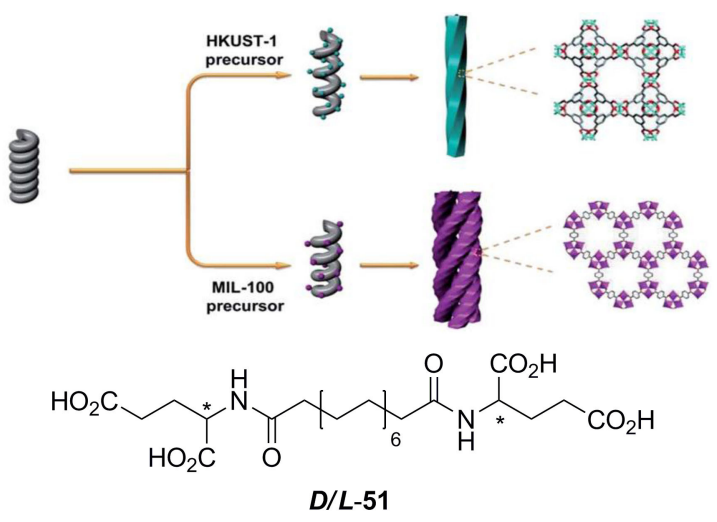

图 $28 D / L-51$ 超分子组装体作为模板构建螺旋纳米结构的 $\mathrm{MOF}^{[82]}$

Figure 28 Fabrication of helical MOF nanostructures by supramolecular assembly templates of $\boldsymbol{D} / \boldsymbol{L}-\mathbf{5 1} \mathbf{1}^{[82]}$

的转录过程也依赖于弱的非共价作用, 转化率较低. 未 来的相关研究将会更加注重于提高超分子手性组装体 作为手性模板时的结构稳定性与材料产率.

\section{2 手性识别}

在生物体高度手性化的环境中, 对映体的手性识别 过程在生命活动中发挥着不可或缺的作用, 具有重要的 理论和实际研究意义, 对该过程进行模拟一直以来都是 化学家努力的方向 ${ }^{[84]}$. 随着越来越多特殊功能结构的 组装基元被开发, 手性识别的肉眼可视化得以通过组装 体颜色的改变、荧光的激发与淬灭、凝胶的形成与坍塌 等过程实现, 为对映体的识别和分离提供了直观方法.

通过动态光散射(DLS)监测囊泡尺寸的变化, 王德 先课题组 ${ }^{[85}$ 实现了超分子手性组装体对阴离子对映体 的手性识别. 手性氧杂杯 [2]芳烃[2] 三嗪衍生物 52 在水 中组装成手性囊泡, 对 $D$-酒石酸阴离子响应, 使囊泡尺 寸显著增加, 而对 $L$-酒石酸阴离子没有响应(图 29). 密 度泛函理论的计算结果表明, 囊泡表面的手性空腔与阴 离子之间存在氢键和阴离子 $-\pi$ 作用, 二者协同实现了手 性识别过程.

刘鸣华课题组 ${ }^{[86]}$ 报道了一例通过组装体肉眼可见 颜色变化实现的手性识别. 在氢键和疏水作用驱动下, 末端用 $L$-谷氨酸修饰的丁二炔两亲性分子 53 在甲醇/水 中组装成囊泡和螺旋结构, 在紫外光辐照下由于丁二炔 的聚合呈现宏观的蓝色. 在组装和光聚过程中, 谷氨酸 的固有手性成功转移到聚丁二炔片段中, 囊泡和螺旋在 $\mathrm{CD}$ 光谱上表现出相反的手性信号. 有趣的是, 尽管囊 泡和螺旋的超分子手性相反, 但对手性分子叔丁基亚磺 胺(TBSA)具有相同的对映体选择性: 加入 $S$-TBSA 的组 装体变为红色, 而加入 $R$-TBSA 时保持蓝色(图 30). 识 别过程依赖 $L$-谷氨酸末端羧基与 TBSA 的氢键作用, 由 羧基构成的手性组装体表面决定着对映体识别的选择
性.

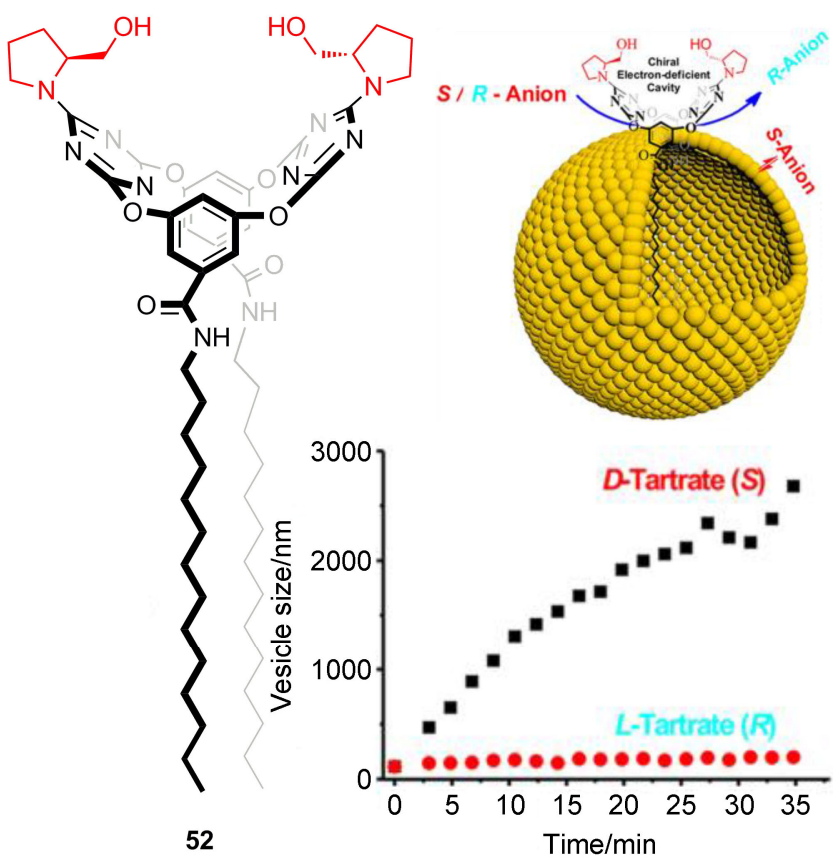

图 2952 的化学结构及其囊泡对 $D / L$-酒石酸阴离子响应的 DLS 检测结果 ${ }^{[85]}$

Figure 29 Chemical structure of $\mathbf{5 2}$ and response of vesicles self-assembled from $\mathbf{5 2}$ to $D / L$-tartrate monitored by DLS ${ }^{[85]}$

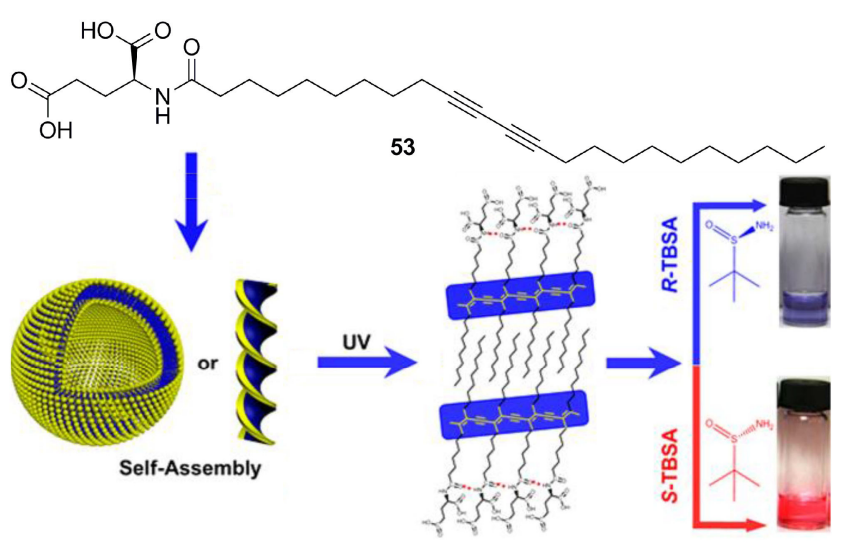

图 3053 的组装体结构模型及其对 $R / S$-TBSA 的响应 ${ }^{[86]}$

Figure 30 Structure model of assemblies $\mathbf{5 3}$ and its responses to $R / S$-TBSA ${ }^{[86]}$

Shinkai 等 ${ }^{[87]}$ 设计了基于寡聚对苯撑乙烯骨架的手 性苂光传感器 $\mathbf{5 4}$. 在甲醇/水中 $\mathbf{5 4}$ 以 $\mathrm{H}$ 型堆积方式得到 弱苂光纤维, 但 1,2-环己基二羧酸(CHDA)能通过氢键 作用使组装体转变为 $\mathrm{J}$ 型堆积, 点亮荧光. 由于 $R R / S S$ CHDA 在接触超分子手性组装体时位阻效应不同, 54/RR-CHDA 比 54/SS-CHDA 体系的荧光强度更高, 从 而在荧光强度上实现对这组对映体的手性识别(图 31). 并且在向 54 组装体中加入 CHDA 两种对映体的混合物 时，体系荧光强度与对映体比例有良好的线性关系，基 于此可以测定对映体中两种构型的比例. 

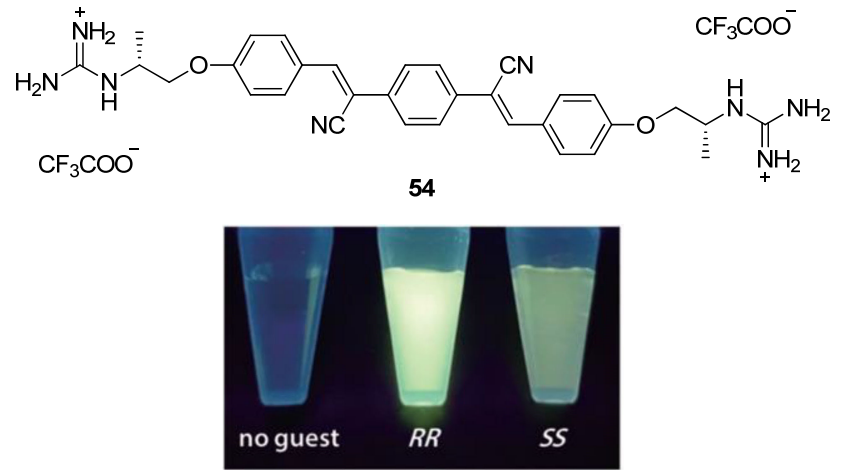

图 3154 的化学结构及其组装体识别 $R R / S S$-环已烷二羧酸后 的苂光变化 ${ }^{[87]}$

Figure 31 Chemical structure of $\mathbf{5 4}$ and fluorescent change of assembled 54 in the presence of $R R / S S-\mathrm{CHDA}^{[87]}$

聚合物的超分子手性组装体同样能应用于手性识 别领域中. 利用聚苯乙烯一聚丙烯酸嵌段共聚物 55 与 $R-1,1^{\prime}$-联䒺衍生物 $\boldsymbol{R}-\mathbf{5 6}$ 的共组装, 朱亮亮等 ${ }^{[88}$ 制备了一 种超分子手性凝胶. $\boldsymbol{R}-\mathbf{5 6}$ 的手性通过氢键和微观相分离 作用传递到聚合物中, 使共组装体对手性环境高度敏 感. 如选用 $\boldsymbol{R}-56$ 参与形成共组装体, 凝胶对 $S$-型手性底 物产生响应, 转变为胶束, 发生宏观可见的凝胶坍塌 (图 32). 如选用 $\boldsymbol{S}$-56, 凝胶在加入 $R$-型手性底物时佣塌. 此外, 该凝胶可识别多种结构类型的手性化合物, 包括 中心手性(苯甘醇等)、轴手性(联菜二酚等)、平面手性(1二茂铁乙醇)和手性聚合物(聚乳酸), 有望在广谱性手性 识别中发挥价值.

将超分子手性组装体用于手性识别为对映体的鉴 别区分提供了新途径, 并且随着相关研究的发展, 特定 小分子化合物的手性识别过程直观可视, 不再过度依赖 仪器设备. 但是, 目前这方面的基础理论研究仍有欠缺, 对手性识别过程中组装体与客体分子之间的作用机制 还只能进行简单的推断与模拟, 有目的地设计合成能够 手性识别靶向对映体分子的组装体仍是一个极大挑战. 与此同时, 超分子手性组装体在手性识别上的适用客体 分子种类也受限, 鲜有广谱性识别体系的报道. 为解决 这些局限性，超分子手性组装结构与手性识别性质间的
关系还需不断深入探索.

\section{3 圆偏振发光}

圆偏振发光 (Circularly Polarized Luminescence, $\mathrm{CPL}$ ) 是指手性发光物质受激发后产生左旋或右旋圆偏 振光的现象. CPL 材料在 3D 成像、数据储存、光电器件、 光催化不对称反应等领域具有潜在应用价值, 受到研究 者的广泛关注 ${ }^{[89]}$. CPL 材料的发光性能可用两个参数表 征：一是荧光量子产率 $(\Phi)$, 它表示材料的发光强度; 二 是不对称发光因子 $\left(g_{\text {lum }}\right)$, 它代表材料发光的手性偏向, 可通过发光中左旋圆偏振光强度 $\left(I_{\mathrm{L}}\right)$ 与右旋圆偏振光的 强度 $\left(I_{\mathrm{R}}\right)$ 进行计算 $\left(g_{\text {lum }}=2\left(I_{\mathrm{L}}-I_{\mathrm{R}}\right) /\left(I_{\mathrm{L}}+I_{\mathrm{R}}\right)\right)$. $g_{\text {lum }}$ 值在 $-2 \sim+2$ 之间, 其绝对值越大, 表明材料性能越好.

应用于 CPL 的超分子手性组装体有两种类型，一 种是由有机手性苂光分子构成的组装体, 另一种是加入 荧光剂的非荧光手性组装体. 对于第一种类型, 虽然有 机手性荧光分子的 $g_{\text {lum }}$ 通常较低, 但形成超分子手性组 装体后荧光团被限域在手性的空间中，体系的 $g_{\text {lum 会显 }}$ 著提升 ${ }^{[90]}$. 例如, Kawai 等 ${ }^{[91]}$ 合成的以荴酰亚胺为苂光 团的手性环己烷二胺衍生物 57(图 33)在 $630 \mathrm{~nm}$ 处的 $g_{\text {lum }}$ 值仅为 $8 \times 10^{-3}$, 但形成螺旋纤维后, 芢酰亚胺基团 处于手性的超分子排列中, $630 \mathrm{~nm}$ 处的 $g_{\mathrm{lum}}$ 值提高到 $2 \times 10^{-2}$. 该体系第一次利用超分子手性自组装手段使 有机苂光化合物的 $g_{\text {lum }}$ 显著提高.

荧光量子产率 $(\Phi)$ 也是 CPL 材料的重要性能参数之 一, 在提高材料 $g_{\text {lum }}$ 的同时需要避免组装体出现聚集苂 光淬灭现象, 为此, 许多具有聚集诱导发光(AIE)性质 的超分子组装基元被用于 CPL 领域 ${ }^{[92]}$. 唐本忠课题 组 ${ }^{[93]}$ 利用具有 AIE 性质的超分子手性组装体实现了圆 偏振发光, 兼具高荧光量子产率和不对称发光因子. 他 们通过 Click 反应合成了甘露糖为手性源、四苯基噻咯 为苂光基团的组装基元 $\mathbf{5 8}$. 在二氯甲烷溶液中 $\mathbf{5 8}$ 只有 微弱的苂光, $\Phi$ 仅为 $0.6 \%$, 在 $\mathrm{CD}$ 光谱中没有信号, 说明 手性从未能传递至四苯基噻咯. 当向二氯甲烷中加入正 己烷后，三氮唑基团间弱 $\pi-\pi$ 作用和非传统 $\mathrm{C}-\mathrm{H} \cdots \mathrm{N} / \mathrm{O}$ 型氢键驱动 58 组装成右手螺旋纤维(图 34). 在聚集

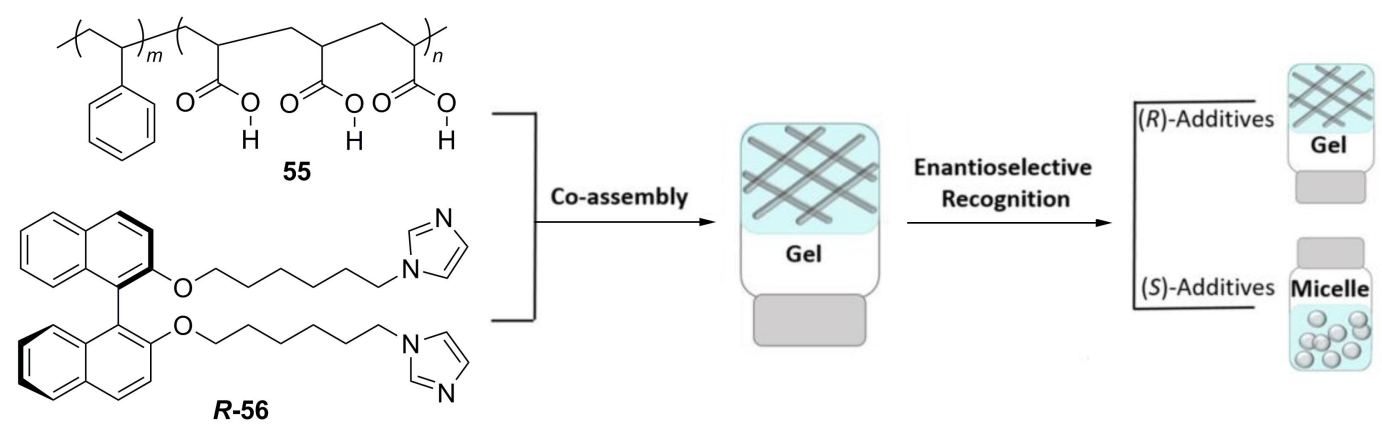

图 $3255, \boldsymbol{R}-56$ 的化学结构及其共组装、手性识别过程示意图 ${ }^{[88]}$

Figure 32 Chemical structures of $\mathbf{5 6}, \boldsymbol{R}-\mathbf{5 6}$ and schematic representation of their co-assembly and enantioselective recognition ${ }^{[88]}$ 


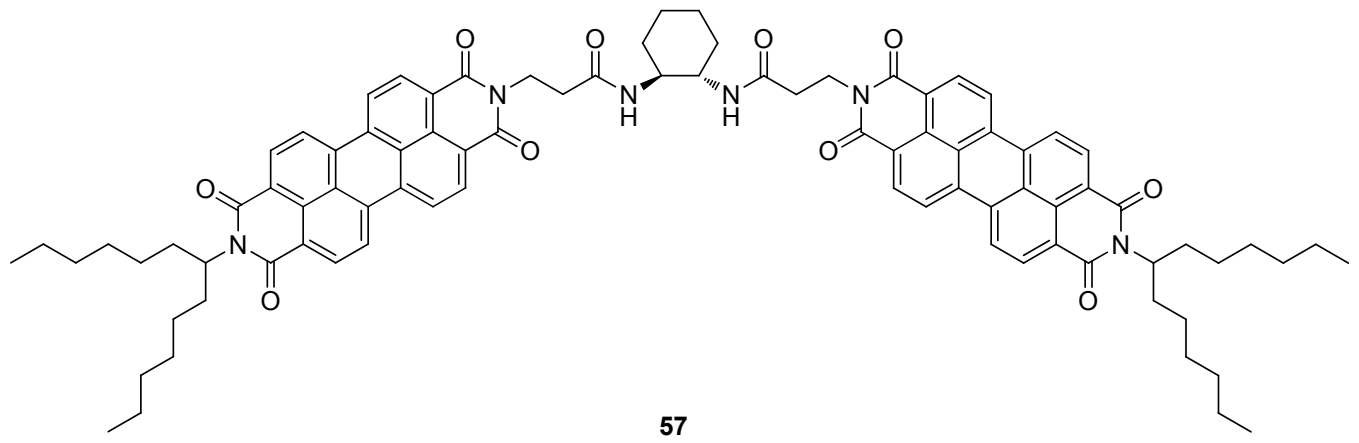

图 3357 的化学结构 ${ }^{[91]}$

Figure 33 Chemical structure of $\mathbf{5} 7^{[91]}$
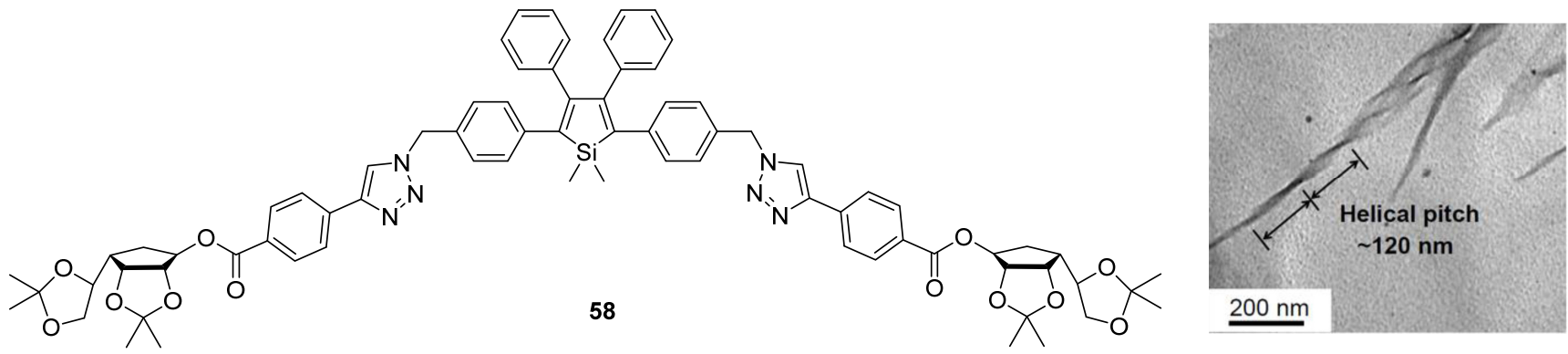

图 34 具有 AIE 活性的手性分子 $\mathbf{5 8}$ 及其组装体的透射电镜图 ${ }^{[93]}$

Figure 34 Chiral AIE-active molecule 58 and TEM image of its assembly ${ }^{[93]}$

态下, 能量无法通过噻咯基团上苯环的自由转动耗散, 体系的苂光量子产率提高到 $81.3 \%$, 手性从甘露糖基团 传递至四苯基噻咯中, 使体系发射的苂光表现出圆偏振 性质 $\left(g_{\text {lum }}\right.$ 约为 -0.32$)$.

在第二种类型中, 虽然超分子手性组装体自身没有 苂光性质, 但基元与外加苂光剂间的手性传递可实现圆 偏振发光, 该方法最初由 Ihara 等 ${ }^{[94]}$ 提出. 他们通过向 谷氨酸吡啶盐衍生物 59 的纤维结构中加入苂光染料构 筑二元共组装体系, 利用手性从组装体到苂光染料的传 递, 实现蓝色 (萠磺酸)、绿色 (还原黄 33) 和红色 (NK-2012)的 CPL 发射(图 35), 且通过改变 59 中谷氨酸 的手性实现了 CPL 的偏振取向翻转. 这类二元体系 CPL 材料的优势在于发光颜色通过染料进行调节, 有希望通 过控制超分子手性将体系作为 CPL 光学开关.

通过对 “手性组装基元十苂光剂” 这一体系进行 扩展, 刘鸣华课题组 ${ }^{[95}$ 提出了一种合成具有可控 CPL 活性的荧光量子点的新方法. 烷基链修饰的谷氨酸衍生 物 60 能形成微观形貌为手性纳米管的凝胶, 核壳结构 的量子点 $(\mathrm{QDs})$ 与 60 间的氢键和电荷作用使量子点沿手 性纳米管生长. 这些非共价作用有效实现了手性从超分 子组装体到量子点的转移, 使量子点的荧光圆偏振化 (图 36). 单体形式的 60 与量子点混合后不能产生 CPL, 说明手性转移过程不是以小分子形式进行的. 作者通过 改变复合凝胶中各发光量子点的比例, 制备出全彩和混
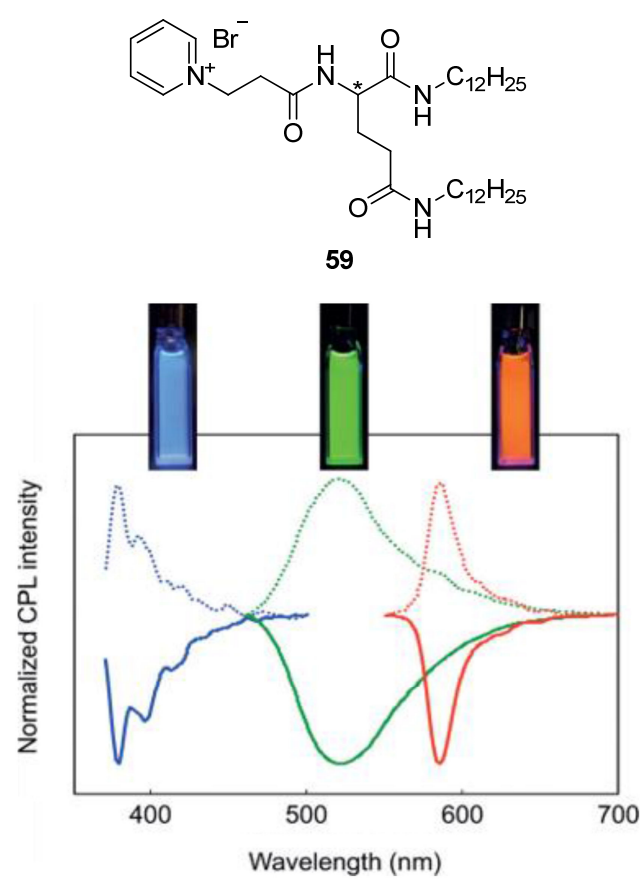

图 3559 的化学结构及其与荧光染料共组装得到的 CPL 光 谱 $[94]$

Figure 35 Chemical structure of $\mathbf{5 9}$ and CPL spectra of fluorescent dye co-assembled with $\mathbf{5 9}^{[94]}$

合白光的 CPL 量子点材料, 为制备丰富多彩的 CPL 材 料提供了新思路. 


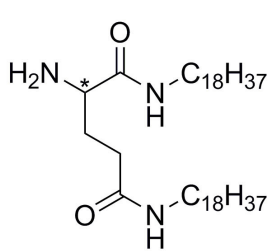

60

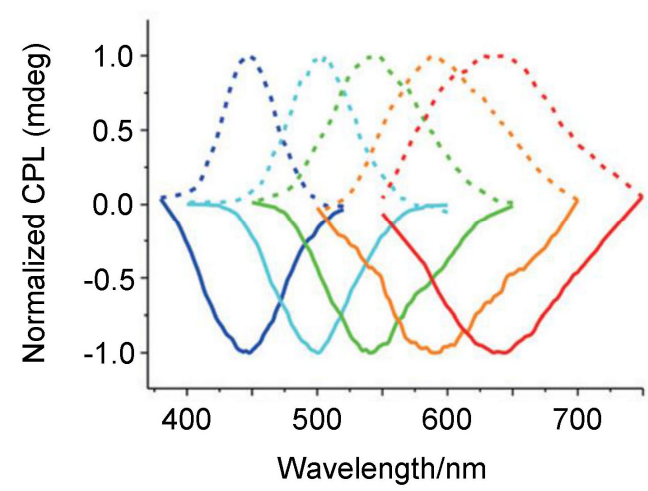

图 3660 和量子点的化学结构及它们共组装体的全彩 CPL 光 谱 ${ }^{[95]}$

Figure 36 Chemical structures of 60, QDs and the full-color CPL spectra of their co-assemblies ${ }^{[95]}$

相比于已经得到广泛研究的稀土金属化合物, 超分 子手性组装体在圆偏振发光领域有着更易调节的发光 范围和更高的量子发光效率. 但在不对称发光因子上, 有机圆偏振发光材料距离稀土金属化合物仍有一定差 距, 主要原因在于前者的 $g_{\text {lum }}$ 通常难以达到稀土金属化 合物的量级, 且聚集态和游离态下有机分子的 $g_{\text {lum }}$ 存在 数量级的区别, 材料性能受组装体结构稳定性的显著影 响. 因此, 构建同时具有高苂光量子产率和高不对称因 子的超分子手性组装体系将会成为未来的研究趋势 ${ }^{[96]}$.

\section{4 不对称催化}

手性催化作为有机化学最活跃的研究领域之一, 愈 来愈多的新催化理念被不断提出. 超分子组装体能够提 供精细规整的纳米结构和限域环境, 某些程度上具有与 酶相似的性质, 用于催化化学反应 ${ }^{[97,98]}$. 当手性被引入 组装体后, 组装体具有的手性结构使其在不对称催化领 域的应用成为可能 ${ }^{[99]}$.

超分子手性组装体用于不对称催化的研究早期, 基 于手性吡咯烷结构的脯氨酸催化给予研究人员大量启 发. 例如 Barbas 课题组 ${ }^{[100]}$ 设计合成了长烷基链修饰的 手性吡咯烷衍生物 61(图 37), 其在水中形成的胶束可用 于催化对硝基苯甲醛和环己酮的不对称 Aldol 反应, ee 值可达 $94 \%$. Clarke 等 ${ }^{[101]}$ 发现 1,8 -荎啶修饰的脯氨酸衍 生物 62 与吡啶酩衍生物 63 能通过氢键组装(图 37), 组 装体对 Michael 加成反应具有不对称催化效果, ee 值为 $79 \%$.

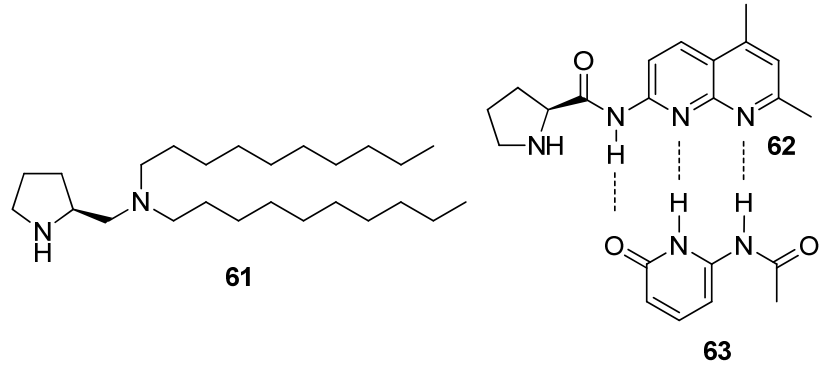

图 $3761 \sim 63$ 的分子结构 ${ }^{[100-101]}$

Figure 37 Chemical structures of $\mathbf{6 1} \sim \mathbf{6 3}^{[100-101]}$

Parquette 等 ${ }^{[102]}$ 发现 $L$-脯氨酸- $L$-赖氨酸二肽衍生物 64 能在水中组装成纳米纤维、管和螺旋的混合结构, 加 入 Aldol 反应的两种底物后形成尺寸均一的纳米管, 催 化不对称 Aldol 反应, $e e$ 值可达 $97.5 \%$ (图 38). 组装体本 身可以通过超离心沉淀反复利用, 重复几次后仍然具有 良好的催化性能. 当组装体被有机溶剂破坏后, 不对称 催化能力丧失, 证明在催化过程中发挥作用的是超分子 手性组装体而不是手性基元本身.

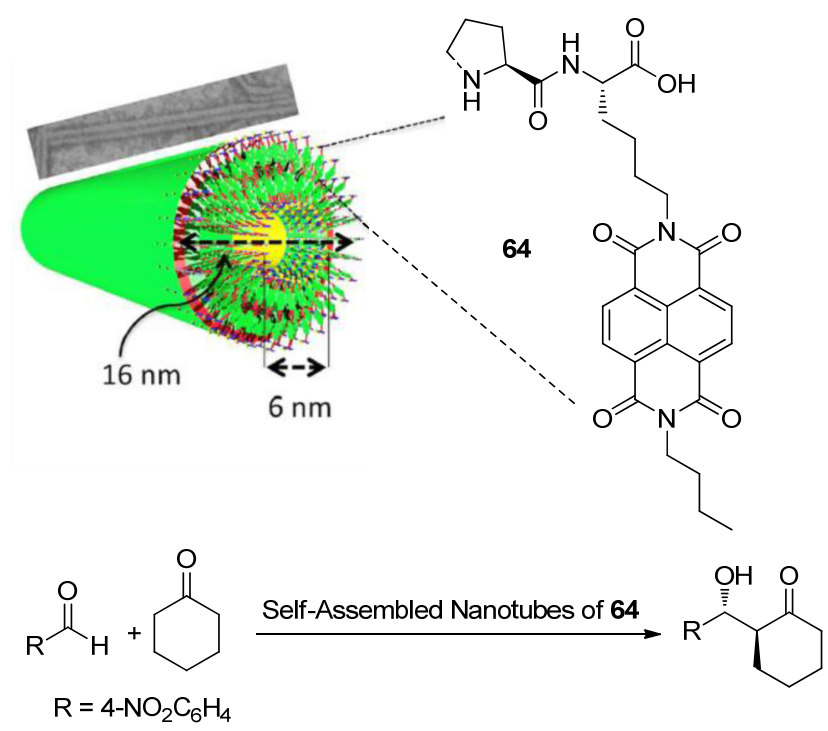

图 3864 组装形成的纳米管与它催化的不对称 Aldol 反应 ${ }^{[102]}$ Figure 38 Nanotubes self-assembled from 64 and the asymmetric aldol reaction catalyzed by these nanotubes ${ }^{[102]}$

近年来随着研究的不断发展, 利用超分子手性组装 体吸附催化反应的金属中心来实现不对称催化的策略 逐步成熟. Raynal 课题组 ${ }^{[103]}$ 设计合成了均苯三甲酰胺 衍生物 65.65 分子结构的双臂被手性烷基链修饰, 另一 含膦分子臂作为金属配体(图 39). 65 在正己烷中组装成 手性纳米棒, 通过与 $\mathrm{Rh}$ 原子的配位诱导 $\mathrm{Rh}$ 络合物手性 排列，从而催化亚甲基丁二酸二甲酯的不对称氢化反 应, $e e$ 值为 $82 \%$. 当另一种均苯三甲酰胺衍生物 $\mathbf{6 6}$ 与 $\mathbf{6 5}$ 共组装时, 反应 $e e$ 值提高至 $88 \%$. 此外, 65 无法在二氯 甲烷中形成超分子手性组装体, 反应只得到外消旋产 
物, 说明组装体中基元的手性排列对不对称催化过程是 必要的.

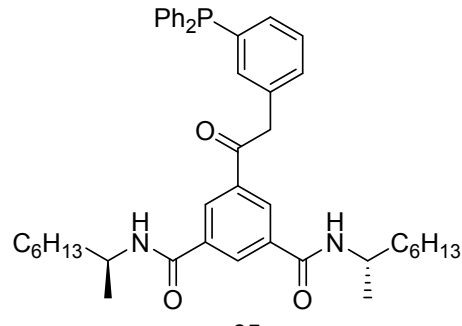

65

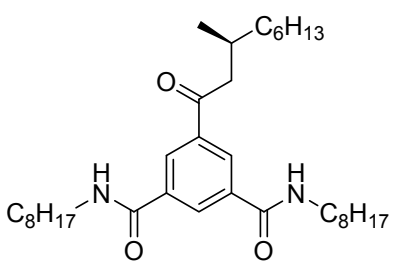

66

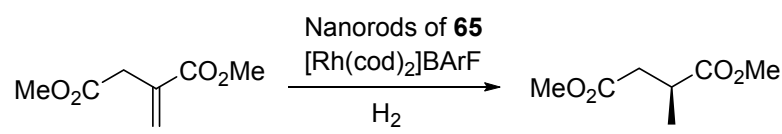

图 3965,66 的化学结构与纳米棒催化的不对称氢化反应 ${ }^{[103]}$ Figure 39 Chemical structures of $\mathbf{6 5}, \mathbf{6 6}$ and the asymmetric hydrogenation catalyzed by nanorods of $\mathbf{6 5}^{[103]}$

刘鸣华课题组 ${ }^{[104-107]}$ 在组装体不对称催化方面上取 得了一系列显著成果. 他们发现谷氨酸两亲性分子 $\boldsymbol{L}-67$ 和 D-67 在水中分别形成左手螺旋纳米管(图 40a) 和右手螺旋纳米管(图 40b). 他们使用左手螺旋纳米管 络合铜离子, 成功催化不对称 Dies-Alder 反应 ${ }^{[105]}$. 螺旋 纳米管表面手性排列的羧基通过与铜离子络合, 诱导铜 离子发生手性排列, 与新加入的反应底物氮杂查尔酮络 合，诱导反应底物发生手性排列，从而产生立体选择性 (图 40c). 同时, 螺旋纳米管的立体结构限制了反应底物 的进攻方向, 表面紧密排列的大量羧基具有协同富集的 作用，进一步提升了反应的立体选择性和反应速率. 使 用该组装体作为催化剂, 反应可在 $1 \mathrm{~h}$ 内完成, ee 值达 $91 \%$ 。当组装体被碱或有机溶剂破坏后, 反应速率大大 降低, 产物外消旋化, 证明发挥不对称催化作用的是超 分子手性自组装体而非单独的手性小分子.

随后, 刘鸣华课题组还发现该螺旋纳米管在络合吸 附不同金属活性中心时, 可以催化不同的有机化学反 应：纳米管与 $\mathrm{Bi}^{3+}$ 络合后可催化不对称 MukaiyamaAldol 反应, $e e$ 值高达 $97 \%{ }^{[105]}$; 吸附 $\mathrm{Rh}$ 络合物时, 可催 化手性环丙烷类化合物的合成 ${ }^{[106]}$; 吸附四丙烯基锡时, 可催化酮的不对称亲核加成反应 ${ }^{[107]}$, 极大地扩展了组 装体的应用范围.

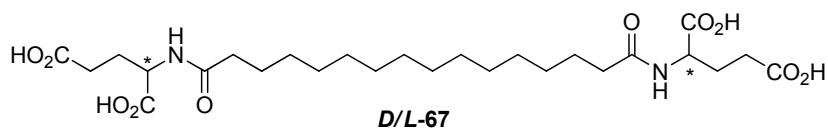
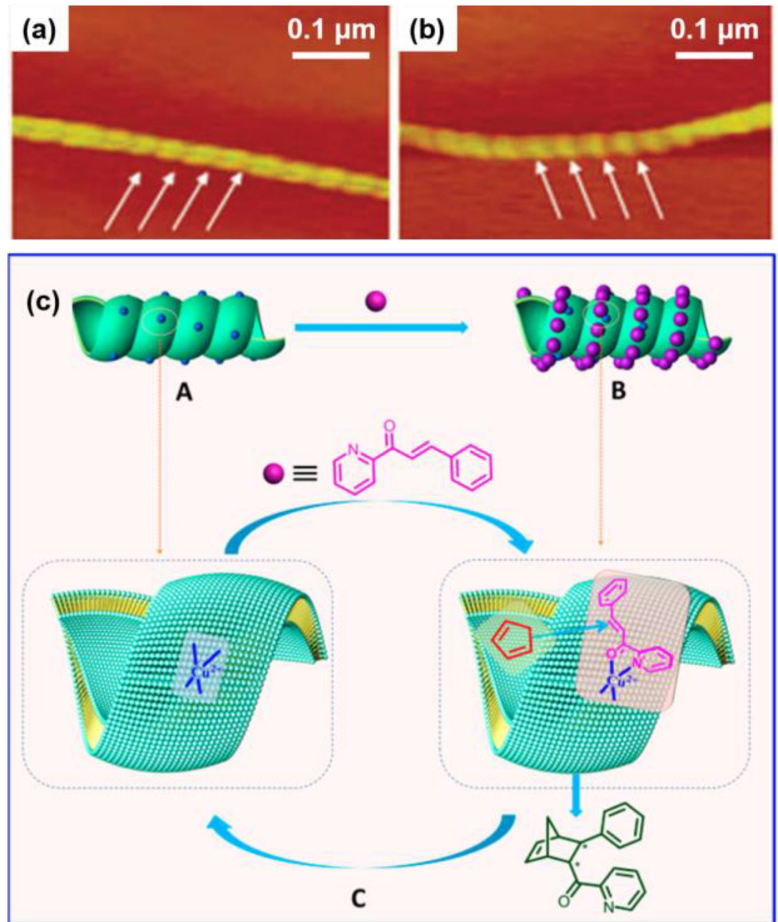

图 40 (a) $L-67$ 和(b) $D-67$ 的化学结构与原子力显微镜下的螺 旋组装体 ${ }^{[104]}$, 以及 (c) 螺旋纳米管不催化 Dies-Alder 反应的机 理 $^{[105]}$

Figure 40 Chemical structures and AFM images of the helical assemblies of (a) $L-67$ and (b) $D-67^{[104]}$, and (c) proposed mechanism of asymmetric Diels-Alder reaction catalyzed by helical nanotubes ${ }^{[105]}$

目前, 超分子手性组装体在不对称催化领域的相关 研究较少, 主要原因在于组装体的形成依赖于组装基元 间的非共价相互作用，对温度、酸碱度等环境因素十分 敏感，使组装体可适用的催化底物和反应类型均受限 制. 但这一研究的基本思路与理念已经愈发成熟：使用 手性微弱、不具备催化性能的小分子构建超分子手性组 装体，通过手性传递、累计、放大过程，使其在不对称 催化性能上较单个小分子显著增强，展现出小分子所不 具备的不对称催化效应 ${ }^{[97,108]}$. 随着组装基元类型的不 断丰富, 超分子手性组装体在不对称催化领域将会发挥 越来越大的价值.

\section{4 结论与展望}

利用手性基元组装、或是利用手性诱导和对称性破 缺使非手性基元组装成超分子手性组装体的设计思路, 人们成功设计并制备出多种结构与性质的超分子手性 组装体，并应用在手性模板、手性识别、圆偏振发光和 
不对称催化等领域. 尽管相关研究已取得长足进步, 但 目前分子手性与超分子手性间的传递关系仍不明晰，如 何构建具有特定手性特征的组装体还需要在理论上进 行深入发掘. 在应用领域, 尤其是不对称催化中, 受限 于组装基元间的弱分子间相互作用, 超分子手性组装体 结构稳定性差、普适性低的问题亟待解决. 超分子手性 与 DNA 复制、蛋白质合成等重要生命活动息息相关, 超 分子手性组装体的生理活性研究也需要人们不断探索. 随着对超分子手性研究的不断深入, 超分子手性组装体 的构建方法将越发成熟，在应用领域中的优势将被充分 发挥, 长期困扰科学家的手性起源问题有望得到解答.

\section{References}

[1] Cahn, R. S.; Ingold, S. C.; Prelog, V. Angew. Chem. Int. 1966, 5, 385.

[2] Smith, D. K. Chem. Soc. Rev. 2009, 38, 684.

[3] Brizard, A.; Oda, R.; Huc, I. Top. Curr. Chem. 2005, 256, 167.

[4] Simonyi, M.; Bikádi, Z.; Zsila, F.; Deli, J. Chirality 2003, 15, 680.

[5] Duan, P. F.; Zhu, X. F.; Liu, M. H. Chem. Commun. 2011, 47, 5569.

[6] Cu, J. X.; Zheng, Y. J.; Shen, Z. H.; Wan, X. H. Langmuir 2010, 26, 15508.

[7] Huang, Y. W.; Hu, J. C.; Kuang, W. F.; Wei, Z. X.; Faul, C. F. J. Chem. Commun. 2011, 47, 5554

[8] Xie, Y. Y.; Wang, Y. F.; Qi, W.; Huang, R. L.; Su, R. X.; He, Z. M. Small 2017, 13, 17009.

[9] Cui, J. X.; Liu, A. H.; Guan, Y.; Zheng, J.; Shen, Z. H.; Wan, X. H. Langmuir 2010, 26, 3615.

[10] Xie, F.; Qin, L.; Liu, M. H. Chem. Commun. 2016, 52, 930.

[11] Shin, S.; Lim, S.; Kim, Y.; Kim, T.; Choi, T. L.; Lee, M. J. Am. Chem. Soc. 2013, 135, 2156.

[12] Duan, P. F.; Cao, H.; Zhang, L.; Liu, M. H. Soft Matter 2014, 10, 5428.

[13] Barclay, T. G.; Constantopoulos, K.; Matisons, J. Chem. Rev. 2014, 114, 10217.

[14] Du, X. W.; Zhou, J.; Shi, J. F.; Xu, B. Chem. Rev. 2015, 115, 13165.

[15] Zhang, L.; Wang, T. Y.; Shen, Z. C.; Liu, M. H. Adv. Mater. 2016, $28,1044$.

[16] Gao, Y. X.; Liang, Y.; Hu, J.; Ju, Y. Prog. Chem. 2018, 30, 737 (in Chinese). (高玉霞, 梁云, 胡君, 巨勇, 化学进展, 2018, 30, 737.)

[17] Delbianco, M.; Bharate, P.; Varela-Aramburu, S.; Seeberger, P. H. Chem. Rev. 2016, 116, 1693.

[18] Chabre, Y. M.; Roy, R. Chem. Soc. Rev. 2013, 42, 4657.

[19] Jung, J. H.; John, G.; Masuda, M.; Yoshida, K.; Shinkai, S.; Shimizu, T. Langmuir 2001, 17, 7229.

[20] Birchall, L. S.; Roy, S.; Jayawarna, V.; Hughes, M.; Irvine, E.; Okorogheye, G. T.; Saudi, N.; De Santis, E.; Tuttle, T.; Edwards, A. A.; Ulijn, R. V. Chem. Sci. 2011, 2, 1349.

[21] Wang, K. R. Prog. Chem. 2015, 27, 775 (in Chinese). (王克让, 化学进展, 2015, 57, 775.)

[22] Sun, K.; Xiao, C. Y.; Liu, C. M.; Fu, W. X.; Wang, Z. H.; Li, Z. B. Langmuir 2014, 30, 11040.

[23] Kobayashi, H.; Friggeri, A.; Koumoto, K.; Amaike, M.; Shinkai, S.; Reinhoudt, D. N. Org. Lett. 2002, 4, 1423.

[24] Rajaganesh, R.; Gopal, A.; Das, T. M.; Ajayaghosh, A. Org. Lett. 2012, 14, 748

[25] Ogawa, Y.; Yoshiyama, C.; Kitaoka, T. Langmuir 2012, 28, 4404.

[26] Fu, I. W.; Markegard, C. B.; Nguyen, H. D. Langmuir 2015, 31, 315 .

[27] Kurouski, D.; Lu, X. F.; Popova, L.; Wan, W.; Shanmugasundaram, M.; Stubbs, G.; Dukor, R. K.; Lednev, I. K.; Nafie, L. A. J. Am. Chem. Soc. 2014, 136, 2302.
[28] Liu, G. F.; Li, X.; Sheng, J. S.; Li, P. Z.; Ong, W. K.; Phua, S. Z. F.; Ågren, H.; Zhu, L. L.; Zhao, Y. L. ACS Nano 2017, 11, 11880.

[29] Wu, X. J.; Ji, S. J.; Li, Y.; Li, B. Z; Zhu, X. L.; Hanabusa, K.; Yang, Y. G. J. Am. Chem. Soc. 2009, 131, 5986.

[30] Sun, Y.; Li, S.; Zhou, Z. X.; Saha, M. L.; Datta, S.; Zhang, M. M.; Yan, X. Z.; Tian, D. M.; Wang, H.; Wang, L.; Li, X. P.; Liu, M. H.; Li, H. B.; Stang, P. J. J. Am. Chem. Soc. 2018, 140, 3257.

[31] Cao, H.; Zhu, X. F.; Liu, M. H. Angew. Chem. Int. Ed. 2013, 52, 4122.

[32] Yuan, Y.; Xiao, Y. W.; Yan, X. S.; Wu, S. X.; Luo, H.; Lin, J. B.; Li, Z.; Jiang, Y. B. Chem. Commun. 2019, 55, 12849.

[33] Nonappaa; Maitra, U. Org. Biomol. Chem. 2008, 6, 657.

[34] Qiao, Y.; Lin, Y. Y.; Wang, Y. J.; Yang, Z. Y.; Liu, J.; Zhou, J.; Yan, Y.; Huang, J. B. Nano Lett. 2009, 9, 4500.

[35] Konikoff, F. M.; Chung, D. S.; Donovan, J. M.; Small, D. M.; Carey, M. C. J. Clin. Invest. 1992; 90, 1155.

[36] Abraham, S.; Vijayaraghavan, R. K.; Das, S. Langmuir 2009, 25, 8507.

[37] Travaglini, L.; D’Annibale, A.; Schillén, K.; Olsson, U.; Sennato, S.; Pavela, N. V.; Galantini, L. Chem. Commun. 2012, 48, 12011.

[38] Liu, G. F.; Sheng, J. H.; Teo, W. L.; Yang, G. B.; Wu, H. W.; Li, Y. X.; Zhao, Y. L. J. Am. Chem. Soc. 2018, 140, 16275.

[39] Li, Y.; Li, G. T.; Wang, X. Y.; Li, W. N.; Su, Z. X.; Zhang, Y. H.; Ju, Y. Chem. Eur. J. 2009, 15, 6399

[40] Lu, J. R.; Ju, Y. Prog. Chem. 2016, 28, 260 (in Chinese). (卢金荣，巨勇，化学进展, 2016, 28, 260.)

[41] Bag, B. G.; Dash, S. S. Nanoscale 2011, 3, 4564.

[42] Bag, B. G.; Dash, S. S. Langmuir 2015, 31, 13664.

[43] Saha, A.; Adamcik, J.; Bolisetty, S.; Handschin, S.; Mezzenga, R. Angew. Chem. Int. Ed. 2015, 54, 5408.

[44] Hu, J.; Zhang, M.; Ju, Y. Soft Matter 2009, 5, 4971.

[45] Gao, Y. X.; Hao, J.; Wu, J. D.; Zhang, X.; Hu, J.; Ju, Y. Nanoscale 2015, 7, 13568.

[46] George, S. J.; de Bruijn, R.; Tomovića, Z.; Van Averbeke, B.; Beljonne, D.; Lazzaroni, R.; Schenning, A. P. H. J.; Meijer, E. W. J. Am. Chem. Soc. 2012, 134, 17789.

[47] Xing, P.; Zhao, Y. L. Acc. Chem. Res. 2018, 51, 2324.

[48] Kaiser, T. R.; Stepanenko, V.; Würthner, F. J. Am. Chem. Soc. 2009, 131,6719 .

[49] Minoia, A.; Destoop, I.; Ghijsens, E.; Feyter, S. D.; Tahara, K.; Tobec, Y.; Lazzaronia, R. RSC Adv. 2015, 5, 6642.

[50] Green, M. M.; Reidy, M. P. J. Am. Chem. Soc. 1989, 111, 6452

[51] van Gorp, J. J.; Vekemans, J. A. J. M.; Meijer, E. W. J. Am. Chem. Soc. 2002, 124, 14759

[52] Palmans, A. R. A.; Vekemans, J. A. J. M.; Havinga, E. E.; Meijer, E. W. Angew. Chem. Int. Ed., 1997, 36, 2648.

[53] Veling, N.; van Hameren, R.; van Buul, A. M.; Rowan, A. E.; Nolte, R. J. M.; Elemans, J. A. W. Chem. Commun. 2012, 48, 4371.

[54] Nie, B.; Zhan, T. G.; Zhou, T. Y.; Xiao, Z. Y.; Jiang, G. f.; Zhao, X. Chem. Asian. J. 2014, 9, 754.

[55] Dudek, M.; Machalska, E.; Oleszkiewicz, T.; Grzebelus, E.; Baranski, R.; Szcześniak, P.; Mlynarski, J.; Zajac, G.; Kaczor, A.; Baranska, M. Angew. Chem. Int. Ed., 2019, 58, 8383.

[56] Avalos, M.; Babiano, R.; Cintas, P.; Jiméne, J. L.; Palacios, J. C. Chem. Rev. 1998, 98, 2391.

[57] Kim, M. J.; Shin, B. G.; Kim, J. J.; Kim, D. Y. J. Am. Chem. Soc. 2002, 124, 3504.

[58] Xu, Y. Y.; Yang, G.; Xia, H. Y.; Zou, G.; Zhang, Q. J.; Gao, J. G. Nat. Commun. 2014, 5, 5050.

[59] Chen, P. L.; Ma, X. G.; Hu, K. M.; Rong, Y. L.; Liu, M. H. Chem. Eur. J. 2011, 17, 12108.

[60] Bailey, J.; Chrysostomou, A.; Hough, J. H.; Cledhill, T. M.; McCall, A.; Clark, S.; Menard, F.; Tamura, M. Science 1998, 281, 672.

[61] Kim, J.; Lee, J.; Kim, W. Y.; Kim, H.; Lee, S.; Lee, H. C.; Lee, Y. S.; Seo, M.; Kim, S. Y. Nat. Commun. 2015, 6, 6959.

[62] Wang, L. B.; Yin, L.; Zhang, W.; Zhu, X. L.; Fujiki, M. J. Am. Chem. Soc. 2017, 139, 13218.

[63] Ribó, J. M.; Crusats, J.; Sagués, F.; Claret, J.; Rubires, R. Science 
2001, 292, 2063.

[64] Micali, N.; Engelkamp, H.; van Rhee, P. G.; Christianen, P. C. M.; Monsù Scolaro, L.; Maan, J. C. Nat. Chem. 2012, 4, 201.

[65] Yuan, J.; Zhang, L.; Huang, X.; Jiang, S. G.; Liu, M. H. Prog. Chem. 2005, 17, 780 (in Chinese). (袁菁, 张莉, 黄昕, 姜思光, 刘鸣华, 化学进展, 2005, 17, 780.)

[66] Hegstrom, R. A.; Kondepudi, D. K. Sci. Am. 1990, 262, 108.

[67] Zhang, J.; Yuan, H.; Cai, J.; Wei, X. H.; Liu, D. S. Sci. Bull. 2016, 61, 630 (in Chinese). (张静, 袁鸿, 蔡瑾, 魏学红, 刘滇生, 科学通报, 2016, 61, 630.)

[68] Sang, Y. T.; Liu, M. H. Symmetry 2019, 11, 950.

[69] Viswanathan, R.; Zasadzinski, J. A.; Schwartz, D. K. Nature 1994, 368,440 .

[70] Yuan, J.; Liu, M. H. J. Am. Chem. Soc. 2003, 125, 5051.

[71] Maity, A.; Gangopadhyay, M.; Basu, A.; Aute, S.; Babu, S. S.; Das, A. J. Am. Chem. Soc. 2016, 138, 11113.

[72] Cantekin, S.; de Greef, T. F. A.; Palmans, A. R. A. Chem. Soc. Rev. 2012, 41,6125

[73] Karunakaran, S. C.; Cafferty, B. J.; Weigert-Muñoz, A.; Schuster, G. B., Hud, N. V. Angew. Chem. Int. Ed. 2019, 58, 1453.

[74] Shen, Z. C.; Jiang, Y. Q.; Wang, T. Y.; Liu, M. H. J. Am. Chem Soc. 2015, 137, 16109 .

[75] Buchs, J.; Vogel, L.; Janietz, D.; Prehm, M.; Tschierske, C. Angew. Chem. Int. Ed. 2017, 56, 280.

[76] Ariga, K.; Mori, T.; Kitao, T.; Uemura, T. Adv. Mater. 2020, 1905657.

[77] Llusar, M.; Sanchez, C. Chem. Mater. 2008, 20, 782.

[78] Sone, E. D.; Zubarev, E. R.; Stupp, S. I. Angew. Chem. Int. Ed. 2002, 41, 1705 .

[79] Gao, Y. X.; Hao, J.; Liu, J. G.; Liang, Y.; Du, F. P.; Hu, J.; Ju, Y. Mater. Chem. Front. 2019, 3, 308

[80] Nakagawa, M.; Kawai, T. J. Am. Chem. Soc. 2018, 140, 4991.

[81] Golla, M.; Albert, S. K.; Atchimnaidu, S.; Perumal, D.; Krishnan, N.; Varghese, R. Angew. Chem. Int. Ed. 2019, 58, 3865.

[82] Wang, H.; Zhu, W.; Li, J.; Tian, T.; Lan, Y.; Gao, N.; Wang, C.; Zhang, M.; Faul, C. F. J.; Li, G. T. Chem. Sci. 2015, 6, 1910.

[83] Savić, S. M.; Vojisavljević, K.; Počuča-Nešić, M.; Živojević, K.; Mladenović, M.; Knežević, N. Ž. Metall. Mater. Eng. 2018, 24, 225

[84] Hembury, G. A.; Borovkov, V. V.; Inoue, Y. Chem. Rev. 2008, 108, 173.

[85] He, Q.; Tuo, D. T.; Ao, Y. F.; Wang, Q. Q.; Wang, D. X. ACS Appl. Mater. Interfaces 2018, 10, 3181 .

[86] Li, S.; Zhang, L.; Jiang, J.; Meng, Y.; Liu, M. H. ACS Appl. Mater.
Interfaces 2017, 9, 37386.

[87] Noguchi, T.; Roy, B.; Yoshihara, D.; Sakamoto, J.; Yamamoto, J.; Shinkai, S. Angew. Chem. Int. Ed. 2017, 56, 12518.

[88] Yue, B. B.; Yin, L. Y.; Zhao, W. D.; Jia, X. Y.; Zhu, M. J.; Wu, B.; Wu, S.; Zhu, L. L. ACS Nano 2019, 13, 12438.

[89] Sang, Y. T.; Han, J. L.; Zhao, T. H.; Duan, P. F.; Liu, M. H. $A d v$ Mater. 2019, 1900110

[90] Kumar, J.; Nakashima, T.; Kawai, T. J. Phys. Chem. Lett. 2015, 6 , 3445.

[91] Kumar, J.; Nakashima, T.; Tsumatori, H.; Mori, M.; Naito, M.; Kawai, T. Chem.-Eur. J. 2013, 19, 14090

[92] Li, H. K.; Li, B. L.; Tang, B. Z. Chem. Asian J. 2019, 14, 674

[93] Liu, J. Z.; Su, H. M.; Meng, L. M.; Zhao, Y. H.; Deng, C. M.; Ng, J. C. Y.; Lu, P.; Faisal, M.; Lam, J. W. Y.; Huang, X. H.; Wu, H. K.; Wong, K. S.; Tang, B. Z. Chem. Sci. 2012, 3, 2737.

[94] Goto, T.; Okazaki, Y.; Ueki, M.; Kuwahara, Y.; Takafuji, M.; Oda, R.; Ihara, H. Angew. Chem. Int. Ed. 2017, 56, 2989.

[95] Huo, S. W.; Duan, P. F.; Jiao, T. F.; Peng, Q. M.; Liu, M. H. Angew. Chem. Int. Ed. 2017, 56, 12174.

[96] Nitti, A.; Pasini, D. Adv. Mater. 2020, 1908021

[97] Jin, Q. X.; Li, J.; Li, X. G.; Zhang, L.; Fang, S. M.; Liu, M. H. Prog. Chem. 2014, 26, 919 (in Chinese).

(靳清贤, 李晶, 李孝刚, 张莉, 方少明, 刘鸣华, 化学进展, 2014, 26,919.)

[98] Fang, W. W.; Zhang, Y.; Wu, J. J.; Liu, C.; Zhu, H. B.; Tu, T. Chem. Asian J. 2018, 13, 712

[99] Jiang, J.; Ouyang, G. H.; Zhang, L.; Liu, M. H. Chem.-Eur. J. 2017, 23, 9439.

[100] Mase, N.; Nakai, Y.; Ohara, N.; Yoda, H.; Takabe, K.; Tanaka, T.; Barbas, C. F. J. Am. Chem. Soc. 2006, 128, 734

[101] Clarke, M. L.; Fuentes, J. A. Angew. Chem. Int. Ed. 2007, 46, 930

[102] Lee, K. S.; Parquette, J. R. Chem. Commun. 2015, 51, 15653.

[103] Raynal, M.; Portier, F.; van Leeuwen, P. W. N. M.; Bouteiller, L. J. Am. Chem. Soc. 2013, 135, 17687.

[104] Jiang, J.; Wang, T. Y.; Liu, M. H. Chem. Commun. 2010, 46, 7178.

[105] Jiang, J.; Meng, Y.; Zhang, L.; Liu, M. H. J. Am. Chem. Soc. 2016, $138,15629$.

[106] Yuan, C. H.; Jiang, J.; Sun, H.; Wang, D. C.; Hu, Y. H.; Liu, M. H. Chem CatChem 2018, 10, 2190.

[107] Sun, H.; Jiang, J.; Sun, Y. M.; Zhang, Q.; Liu, M. H. Chem. Commun. 2019, 55, 3254

[108] Escuder, B.; Rodríguez-Llansola, F.; Miravet, J. F. New J. Chem. 2010, 34, 1044. 